\title{
How might landscapes be better designed to accommodate increasing cremation practices in Europe?
}

\begin{abstract}
Death is one of those universal parameters of life, yet very little attention is given to it in neither the work of planning practitioners nor that of landscape research. During the $19^{\text {th }}$ and $20^{\text {th }}$ century's many Western societies turned to cremation as a more sanitary, less costly and space saving way of human disposal. This paper highlights the cemeteries and crematoria as two types of facilities associated with cremation practices in Poland and in selected European countries. On the basis of analyses of contemporary funerary landscapes for cremation practices from Europe (31 objects from 9 countries) a catalogue (,pattern book') of design solutions was developed. Countries were selected on the basis of similarity to Poland in the aspect of the dominant religion (Austria, France, Italy, Slovakia, Slovenia), convergent provisions of cemetery and funeral law (Austria, Denmark, France, Germany, Slovenia, Sweden), and index of average population served by 1 crematorium (Belgium). Moreover, assessment of Polish contemporary places for cremation (39 objects) was developed. To strengthen the multifaceted meaning of funerary landscape and to link it more with the landscape, design considerations and potential outcomes for improved cemetery design accommodating cremation practices and burial was developed. The funerary landscape is defined as a specific type of landscape that focuses on the phenomenological relation between death, disposal of the body in the environment and the social memory of the group participating in the remembrance of the burial.
\end{abstract}

\section{Keywords:}

funerary landscape, cemetery landscape, crematorium, design solutions, guidelines, bereavement

\author{
Anna Długozima ${ }^{1 *}$ \\ 1) Warsaw University of Life \\ Sciences, Institute of Environmental \\ Engineering, Department of \\ Landscape Art; Poland \\ *Corresponding author: Anna \\ Długozima, Warsaw University \\ of Life Sciences, Institute of \\ Environmental Engineering, \\ Department of Landscape Art, \\ Nowoursynowska Street 166; 02 \\ 787 Warsaw; Poland; E-mail: anna_ \\ dlugozima@sggw.edu.pl
}




\section{Introduction}

\subsection{Justification}

„Death is one of the few universal experiences of human existence. It is the most predictable event in our lives, one that is to be expected with absolute certainty" (Grof and Halifax 1978, p. 1). Moreover, the nature of death is immersed in deep mystery. Art has always been a reflection of the human approach to the issue of death as a background for the phenomenon of death, creating places for funeral rites and a structure for storing the corpses (Humphrey and Vitebsky 1997; Kerrigan 2007). Most of the time, people are buried or cremated at special, intimate, and/or sacred places. All over the world, even since prehistoric times, a lot of attention is given to the last place of the dead (Kok 1994).

Dynamic urbanization and increase in the world's population pose new challenges for humanity. The UN agency dealing with urbanization and human settlements (UN-Habitat) alerts in a global report on human settlements $(2009$, p. 27), that the progressing globalization and multiculturalism forces planners to look for spatial solutions, that eliminate socio-cultural conflicts, especially in the area of religious facilities (which include crematoria and cemeteries) and funeral ceremonies (these issue were a key part of research Maddrell et al. 2018). Nevertheless, death is one of those universal parameters of life, yet very little attention is given to it in neither the work of planning practitioners nor that of landscape research. "During the nineteenth and twentieth century's, many Western societies turned to cremation as a more sanitary, less costly and space saving way of human disposal" (Howarth 2007, pp. 226-227). According to the Eurostat report entitled "Mortality and life expectancy" (https://ec.europa. $\mathrm{eu} /$ ), the ratio of the burden by elderly people (the number of people aged 65 or more per 100 people aged 15-64) will double by 2050 . The increase in this measure proves that aging of the European population will continue. Despite the progress in medicine, which contributes to a constant reduction in mortality and leads to longer life expectancy, all forecasts assume a slow increase in the number of deaths, because the post-war baby boomers enter the post-production age phase (Szukalski 2016). The consequence of this condition will be an increasing death rate and dynamic increase in the demand for space for depositing corpses and debris. It is forecasted that the population in Poland will decrease from around 38.5 million to 34.8 million. This rhetoric is the justification for the need to undertake research in the field of burial form, which is cremation, especially now popular in Europe, including Poland. Growing secularization of society and increasing in the number of people choosing cremation (Palánová et al. 2015) determine that "cremation will continue to be one of the most common forms of disposal in Europe" (Worpole 2003, p. 187).

The argument confirming the legitimacy of conducting the research focused on the landscape for cremation practices is the fact that the Cremation Society of Great Britain has recognized Poland as one of the most dynamically developing markets in cremation services in Europe (https://www.cremation.org.uk/ statistics). From art. 12 of the Act on Cemeteries and Burial of Deceased (1959) in Poland, it follows that the body of a dead person may be buried as a corpse or be cremated. Poland belongs to a small group of countries that impose on citizens the obligation to bury the deceased at the cemetery (Germany, Slovenia, Sweden) (Długozima and Kosiacka-Beck 2020). The law prohibits the scattering of ashes of the deceased person and the storage of the urn with ashes outside the cemetery (Dziewulak 2012). The investment to build a corpse incinerator was specified in the Regulation of the Council of Ministers (2004) on the definition of types of projects that may significantly affect the environment, and detailed conditions related to the qualification of the project to draw up an environmental impact report as having the potential to significantly affect the environment. Therefore, the necessary conditions were: conducting an environmental impact assessment of the project and social consultations. Under the new Regulation of the Council of Ministers (2010) crematoria ceased to be subject to these restrictions. The simplification of procedures resulted in dynamic increase in the number of incinerators in Poland. At the beginning of 2020, according to data of the Polish Funeral Association, there were 63 facilities in the country (compared to 10 crematoria in 2009), which determine a low quality of the landscape for cremation 
practices. As Gajewska rightly notes (2009, p. 279), "the increasing popularity of cremation practices is noticed to a small extent in the research perspective of contemporary Polish science". Also Idem (2015) regrets that the subject of thanatoarchitecture ("thanatos" means death in Greek, the personification of the god of death) is not often taken up in scientific research and design work. Thanatoarchitecture for many people, who have cremated their deceased, is full of memories and loads of religious, spiritual and cultural values. On the other hand, is an architectural, spatial manifestation of public attitudes towards death (Valentijn and Verhoeven 2018). In Polish society, and many other European societies, the subject of contemporary death is a taboo (Kellehear 1984; Walter 1991, 2012; Długozima 2017); nevertheless, the manner of dealing with death constitutes a sign of cultural development and change across time and space (Teather 1998, 1999; Kong 1999; Maddrell and Sidaway 2010; Erikkson 2010).

It should be emphasized, that although cremation is a popular subject of research in Western Europe (Fry 1969; Davies and Mates 2005; especially in Belgium: Javeau 2001; Czech Republic: Nešporová 2007; Hupková 2010, 2014; Svobodová 2013; Nešporová 2020; Norway: Hadders 2013; the Netherlands: Van Steen and Pellenbarg 2006; Klaassens and Groote 2014; Mathijssen 2017; Mathijssen and Venhorst 2019; Sweden: Åhrén 2009; Williams 2011; Great Britain: Grainger 2005; Jupp 2005; Rugg and Parsons 2018), the researchers note that the architectural articulation of the crematorium and design solutions for landscape have not yet been sufficiently "worked" (Klaassens 2012; Swanson 2017; Valentijn an Verhoeven 2018). As Rugg (2006) regarded the increasing popularity of cremation prompts to "reinvent" cemetery aesthetic. Cremationists inform that despite growing social acceptance for cremation, there is still a lack of relevant studies indicating appropriate solutions in the design of cemeteries for cremation practices, crematoria, columbaria, their surroundings and marking connections with landscape. There is also lack of specialized literature for designers and professional public or operators (Palánová et al. 2015). A properly designed landscape for cremation practices is to help in the process of humanizing death and experiencing mourning, so that the society is not threatened by "memory pathology"
(Długozima 2017), called by Shaker Ardekani et al. (2015, p. 60) "cultural Alzheimer". Cremation grounds are the spaces where people assemble and are assembled with both dead and alive, across generations and in recent development, cross-culturally. Therefore, these places of cremation are "those very critical spaces, which may be argued to have an effect on one's space of mind" (Chakraborty and Banerjee 2020, p. 1360). Critics have stated that most crematoria are composed of disparate elements that are uncomfortably resolved. Moreover, they have described the design of crematoria as ,largely a field of wasted opportunities". "There is only the weakest of connections between building and landscape" (Worpole 2003, p. 184). Few crematoria buildings and landscapes have achieved anything like this level of aesthetic and ritual integration (Worpole 2003, p. 185).

In connection with the above, the objectives of this study were as follows to:

1. show multifaceted nature of landscape related to cremation practices (incineration, interment).

2. develop a catalogue ('pattern book') of design considerations and potential outcomes for improved cemetery design accommodating cremation practices in selected European countries.

3. verify design considerations ('pattern book') at selected contemporary spaces for cremation in Poland.

4. develop the recommendations to strengthen the multifaceted meaning of landscape for cremation practices (find assumptions for the design of funerary places in the contemporary landscape).

Most funerary landscapes are hidden, have no connection with the surroundings. Therefore, it was assumed that the funerary landscape is a part of the landscape and it should be visible in the landscape and in the daily life. "Landscapes of the dead are always, simultaneously, landscapes of the living" (Worpole 2003, p. 21). Pattern book - the list of features and principles gives designers, planners, and city officials a basis for understanding options in funerary landscapes design. Moreover, design considerations and potential outcomes are focused on the integration of funeral places (cemetery, crematorium) with the existing landscape, because this gives more identity to the place. 


\section{Cremation in Poland against the European background of phenomenon}

The latest statement prepared by the Cremation Society of Great Britain, containing data from 2018 from over 70 countries around the world, shows that the percentage of funerals preceded by cremation is statistically increasing (https://www.cremation.org.uk/ statistics). Most cremations were carried out in Slovenia (83.91\%), Denmark (83.90\%), Czech Republic (83.07\%), Switzerland (82.28\%), Sweden (82.08\%), United Kingdom (78.19\%) and Germany (67.00\%). The percentage of cremations increased significantly in countries that were at the bottom of the list in 1996. For example: in $2018,50.3 \%$ of corpses were incinerated in Spain (an increase of almost 45\%), in Portugal - $48 \%$ (an increase of almost $40 \%$ ), in Italy - $23.9 \%$ (an increase of almost $21 \%$ ). Poland is also one of the countries, in which the share of cremation is growing dynamically (Figure 1, Table 1).

It should be emphasized, that currently, databases aggregating the number of burials with the division of their form (inhumation or cremation) are not car- ried out in Poland. Polish crematoria do not provide information on the number of incinerations carried out. There is also no central register of crematoria.

Due to the Christianisation of Europe from the Middle Ages up to the nineteenth century, inhumation prevailed (placing the body in a grave modeled on the martyrdom of Jesus Christ) (Ariés 1974; Vovelle 1983). The real world-breakthrough came in the age of Enlightenment. At that time, research on urban cemeteries was carried out on the basis of medicalisation, urbanization and increase of public awareness, from which the need to liquidate them sounded. In this way, the idea of "extra muros" cemeteries was constituted (Ariés 1974). Establishment of modern cemeteries does represent a change in burial behaviour in Europe from the late $18^{\text {th }}$ century (Ariés 1974; Etlin 1984; Rebay-Salisbury 2013). The priority given to hygienic and sanitary issues influenced the dynamic development of the social movement for the recognition of cremation as a method to eliminate any epidemiological threats (Eassie 1875; Leaney 1989; Stępa 1993; Prothero 2001). In 1874, The Cremation Society of Great Britain was founded. Public consent for cremation has contributed to

70

60

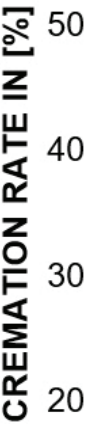

10

0

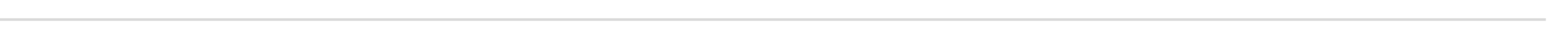

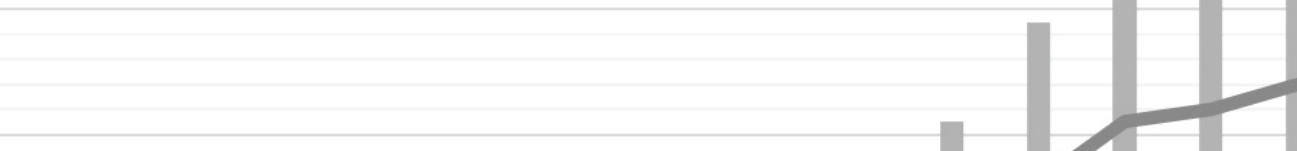

(1)

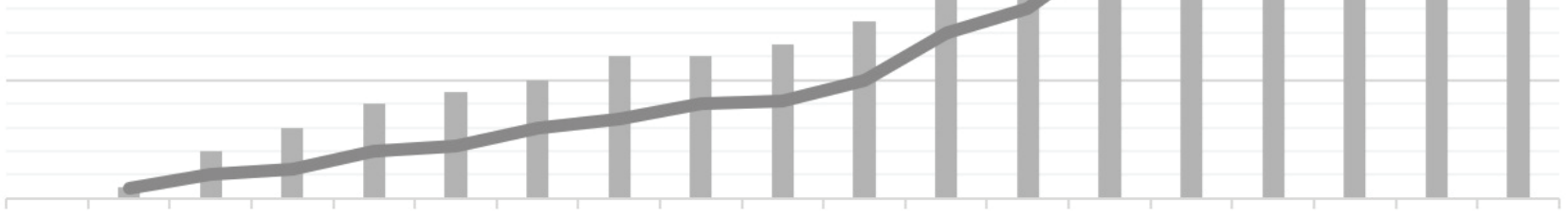

199319972002200320052007200820092010201120122013201420152016201720182019

NUMBER OF CREMATORIA

Figure 1. Number of crematoria and cremation rate* in Poland in 1993-2019. Own elaboration

* cremation rate is the $\%$ share of cremations in the total burial carried out during the year 
Table 1. Crematoria by voivodeships in Poland. Own elaboration

\begin{tabular}{|c|c|c|c|c|c|}
\hline \multicolumn{3}{|l|}{ DATA FOR VOIVODESHIP } & \multicolumn{3}{|c|}{ DATA ON CREMATORIA } \\
\hline Name & Population & Area [ha] & $\begin{array}{l}\text { Number of } \\
\text { crematoria }\end{array}$ & $\begin{array}{l}1 \text { crematorium / num- } \\
\text { ber of inhabitants }\end{array}$ & $\begin{array}{c}1 \text { crematorium / } \\
\text { area }\end{array}$ \\
\hline Dolnośląskie & 2902547 & 1994670 & 9 & 322505 & 221630.0 \\
\hline Kujawsko-Pomorskie & 2082944 & 1797134 & 4 & 520736 & 449283.5 \\
\hline Lubelskie & 2126317 & 2512246 & 2 & 2126317 & 2512246.0 \\
\hline Lubuskie & 1016832 & 1398793 & 3 & 338944 & 466264.3 \\
\hline Łódzkie & 2476315 & 1821895 & 4 & 619079 & 455473.8 \\
\hline Małopolskie & 3391380 & 1518279 & 1 & 3391380 & 1518279.0 \\
\hline Mazowieckie & 5384617 & 3555847 & 8 & 769231 & 507978.1 \\
\hline Opolskie & 990069 & 941187 & 2 & 495035 & 470593.5 \\
\hline Podkarpackie & 2129138 & 1784576 & 4 & 532285 & 446144.0 \\
\hline Podlaskie & 1184548 & 2018702 & 3 & 394849 & 672900.7 \\
\hline Pomorskie & 2324251 & 1832193 & 3 & 774750 & 610731.0 \\
\hline Śląskie & 4548180 & 1233309 & 9 & 505353 & 137034.3 \\
\hline Świętokrzyskie & 1247732 & 1171050 & 2 & 623866 & 585525.0 \\
\hline Warmińsko-Mazurskie & 1433945 & 2417347 & 0 & - & - \\
\hline Wielkopolskie & 3489210 & 2982650 & 3 & 1163070 & 994216.7 \\
\hline Zachodnio-Pomorskie & 1705533 & 2289732 & 6 & 284256 & 381622.0 \\
\hline TOTAL & 38433558 & 31269610 & 63 & 610056 & 512616.6 \\
\hline
\end{tabular}

the legalization of this form of handling the body of the deceased initially in Italy, France, Germany and Great Britain (Parsons 2003; Jupp 2006). In addition to sanitary (ecological, epidemiological safety of the incineration), spatial (problem with obtaining the free areas for inhumation burial), growing secularization of European societies contributed to the popularization of cremation at the end of the 19th century (Colombo 2017). The first crematorium in Poland was opened in 1993 (in Poznań). As 90\% of Poles declare Catholicism, it is worth referring to the Catholic Church's position on cremation. The 2016 Instruction of the Congregation for the Doctrine of the Faith on the burial and cremation shows that there is no doctrinal reason to prohibit cremation for reasons of "hygienic, economic or social type", when it is in accordance with the will of the deceased. It does not touch the soul and "does not prevent the divine omnipotence of the resurrection of the body, and therefore does not contain an objective denial of Christian doctrine on the immortality of the soul and the resurrection of the body" (http://www.vatican.va/). "The church still prefers burial of bodies, as it shows greater respect for the dead; however, cremation is not prohibited, "unless it was chosen for reasons contrary to Christian teaching" (http:// www.vatican.va/). In the case of cremation, "the ashes of the deceased must, in principle, be kept in a holy place, that is, in a cemetery" or in some cases in a church or in an area designated for this purpose by the relevant church authorities. This is conducive to prayer for and remembrance of the dead. Absolutely, "one should not allow the spread of ashes in the air, on the ground or in water or other means, or the processing of creamy ashes into souvenirs, jewellery or other items" (http://www.vatican.va/). It follows from the above that, although the Congregation for the Doctrine and Faith currently does not see doctrinal reasons to prohibit the practice of burning the corpses, the Church prefers to bury human corpses in the land dedicated to cemeteries. This custom is supported by the form of burial of Christ himself, who was buried in a grave carved in the rock (Suchecki 2009). Cremation is gaining popularity in Poland, because it helps to alleviate the problem of overcrowded and unsightly cemeteries, which cause a lot of trouble, especially to the authorities of large cities (Supreme Audit Office 2016). It is enough to quote a 
Table 2. Spatial factor determining popularity of cremation. Cremation versus inhumation. Own elaboration

\begin{tabular}{|c|c|c|}
\hline $\begin{array}{l}\text { Burial type } \\
\text { Feature }\end{array}$ & TRADITIONAL BURIAL (INHUMATION) & CREMATION \\
\hline $\begin{array}{l}\text { Coffin / urn } \\
\text { (dimensions) }\end{array}$ & $0,75-1,1 \mathrm{~m}$ & $0,30-0,35 \mathrm{~m}$ \\
\hline $\begin{array}{l}\text { Grave } \\
\text { (dimensions) }\end{array}$ & $\begin{array}{c}\text { length } 2.0 \mathrm{~m} ; \\
\text { width } 1.0 \mathrm{~m} \text {, } \\
\text { depth } 1.7 \mathrm{~m} ; \\
\text { distance from each side } 0.5 \mathrm{~m}\end{array}$ & $\begin{array}{c}\text { length } 0.6 \mathrm{~m} ; \\
\text { width } 0.4 \mathrm{~m} ; \\
\text { depth } 1.0 \mathrm{~m} ; \\
\text { distance from each side } 0.5 \mathrm{~m}\end{array}$ \\
\hline \multirow{2}{*}{$\begin{array}{l}\text { Repertoire of } \\
\text { development } \\
\text { elements }\end{array}$} & Traditional graves/ Catacombs & $\begin{array}{c}\text { Urn fields/ Memorial gardens / Columbaria / } \\
\text { Crematorium }\end{array}$ \\
\hline & \multicolumn{2}{|c|}{$\begin{array}{l}\text { Park furniture (benches, lights, bins, flower boxes, pergolas) } \\
\text { Cubature objects: funeral parlor, chapel } \\
\text { Pavement, communication system, central square } \\
\text { Gate and fences }\end{array}$} \\
\hline $\begin{array}{l}\text { Cemetery } \\
\text { development } \\
\text { options } \\
\text { (spatial layout, } \\
\text { composition) }\end{array}$ & $\begin{array}{l}\text { rigid, rectangular row arrangement, straight avenues, } \\
\text { large-size casket graves make it difficult to differentiate } \\
\text { the structure of the cemetery; with a rigid arrangement, } \\
\text { greenery limited to a minimum or lack thereof, domi- } \\
\text { nance of gravestones; cemeteries - cities of the dead }\end{array}$ & $\begin{array}{l}\text { possibility of soft, curvilinear shaping, mean- } \\
\text { dering alleys, small urn tombs allow to differen- } \\
\text { tiate the structure of the cemetery by intro- } \\
\text { ducing large spaces of greenery; cemeteries } \\
\text { - gardens, cemeteries - parks, forest cemeteries }\end{array}$ \\
\hline $\begin{array}{l}\text { Spatial } \\
\text { composition }\end{array}$ & 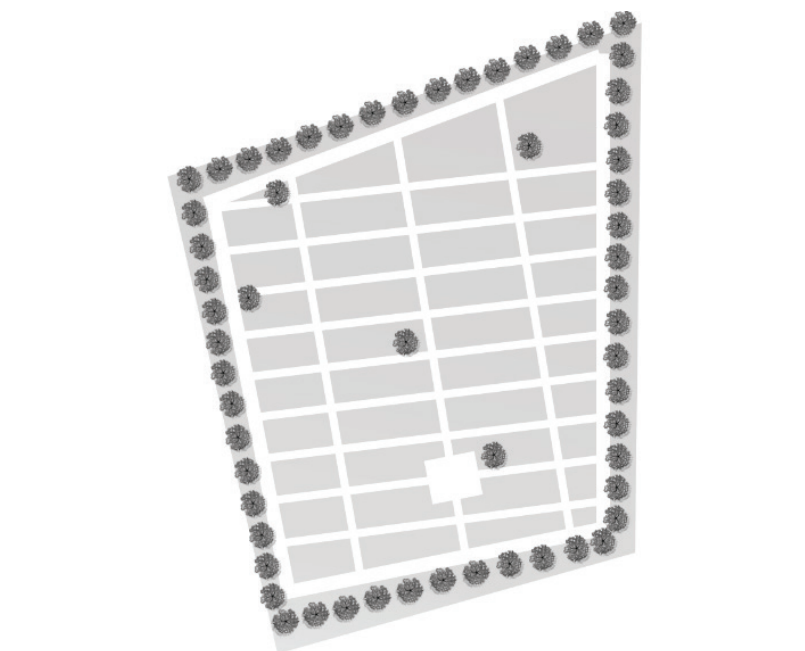 & 3. \\
\hline
\end{tabular}

few figures to outline the spatial advantages of cremation: if 4 coffins are buried on $10 \mathrm{~m}^{2}$, then 200 urns could be placed in a columbarium occupying the same surface. This is a huge saving of land. Urn burial also creates more space arrangement options (possibility of introducing a varied communication system and large green spaces enriching the cemetery's function and improving its aesthetic and social values) (Table 2 ). The increase in the share of crema- tion burials allows to significantly extend the period of operation of the cemetery and its implementation of the burial program. From the calculations of Stępa (1993), the cemetery could take in a period of two and a half times longer than an inhumation object, which cannot be overestimated, especially in cities struggling with problems in acquiring appropriate areas for burial purposes. 
3 Funerary places in the landscape: multifaceted landscape for cremation practices

In this paper the terms: "cremation“, "cemetery", "crematorium", "columbarium", "funerary landscape" will be the principal terms used to denote the places associated with cremation practices in contemporary European society and landscape. The disposal of a corps by means of fire is referred to generally as "cremation". It is the reduction of a dead corpse to ash and bone fragments through rapid oxidation caused by intense heat. There is also the term „urn burial“ to describe the interment of cremated remains in containers in appropriate settings. "Columbarium" is a Latin etymology term ("columba") meaning a type of collective tomb in the form of buildings with niches or closed compartments for storing urns. "Crematorium" means any building fitted with appliances for the purpose of burning human remains, and shall include everything incidental or ancillary thereto. A cultural landscape is defined by UNESCO (1972) as the, "combined works of nature and humankind, that express a long and intimate relationship between peoples and their natural environment." Based on this definition, "funerary landscape" is a specific type of cultural landscape that focuses on the phenomenological relation between death, disposal of the body in the environment and the social memory of the group participating in the remembrance of the burial (Daróczi 2012, p. 202). For the purpose of this paper, the author's attention is focused on the landscape related to death, funeral rites, and various forms of worship of the dead in the aspect of cremation practices (funerary landscape for cremation: storing the ashes after their cremation, solutions used to preserve the memory of the dead using specific design elements). According to the law in force in Poland, the body of the deceased, also cremated, can only be buried in the cemetery. In connection with the above, cemeteries and crematoria are the most important facilities of funerary landscape related to cremation. At a crematorium, the deceased are incinerated in an oven after the ceremony. At a cemetery, the human ashes are deposited in urn field, columbarium or garden of remembrance. According to Polish law regulations, the ashes of the deceased are not allowed to be scattered.

The main function of funerary landscape is facilitating burials, cremations and the placement of ashes. Mourning, remembrance and contemplation are corresponding functions (Keddemann 2011, p.
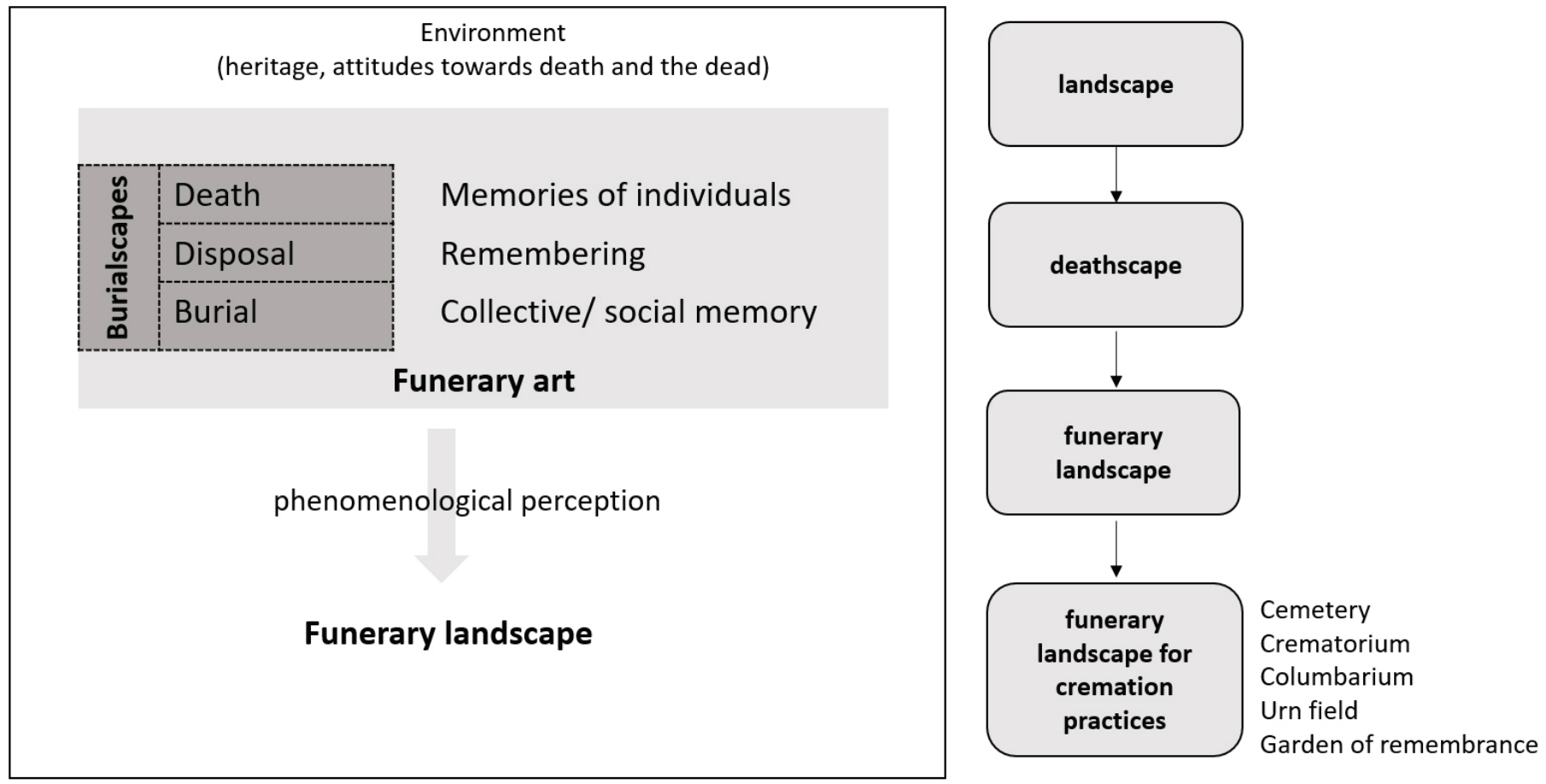

Figure 2. Funerary landscape for cremation practices as a specific type of cultural landscape. Own elaboration based on (Keddemann 2011, Daróczi 2012) 
7). To create multifaceted landscape for cremation practices it is important to explore the death phenomena, its expression through an architectural and landscape lens (Pham 2014). Cemeteries and crematoria are funeral facilities subject to other laws, called by Lewicka (2017) enclave laws. They belong to space, but they are somehow separated from it due to the "Thanatos process" carried out in them, during which society, based on established socio-cultural norms, "deals with the corpse" (Thomas 1980). Proxemic research indicates that the manner and quality of arrangement of those fragments of space that have been annexed by cemeteries and crematoria, significantly affects the suppression or release of emotions (Hamilton 2006; Burns 2011; Bil 2014). Moreover, cemeteries and crematoria in accordance with Polish law are architectural and religious objects. Polish Classification of Building Facilities (1999) includes these facilities in class 1272 ("Buildings intended for religious worship and religious activities"). This class includes two categories: 1 ) "Churches, chapels, Orthodox churches, mosques, synagogues, etc." and 2) "Cemeteries and related facilities, funeral parlors, and crematoria". The process of incineration of human corpses means that new elements, forms of commemoration dedicated to depositing the incinerated corpses such as columbaria, memorial gardens and urn fields appear in the landscape. The standard solutions used in Poland and Europe, which are the emanation of cremation, are: crematoria, columbaria, gardens of remembrance and urn fields.

Literature review show that the design of landscape for cremation practices is not just utilitarian pieces for processing death and disposal, but also a process of consoling the bereaved through architectural, sacred and landscape. It is important to think of bereavement as multidimensional events (Bowlby 1969; Day 1990; Berry 1992; Davies 1996; Mitrione and Larson 2007; Ward 2010; Keddermann 2011; Pham 2014; McCoyd and Walter 2016). Designing for bereavement is a multifaceted process. As Keddemann stated $(2011$, p. 8) "funerary places are ritual places. Funerary rituals mark the transition from life to death. Rituals makes people know what they have to do in a dramatic situation; they can express their grief and new social classifications can by clarified. People need rituals in difficult situations, and they play an important role during the mourning process" (Figure 3). It is important to highlight that the process of bereavement is not a linear one with concrete boundaries. It is instead consists of phases that depend on the person and situation. The phases of bereavement are meant to be general guidelines to allow us to understand the emotional process and physical symptoms endemic to a loss (Sanders 1999; Pham 2014).

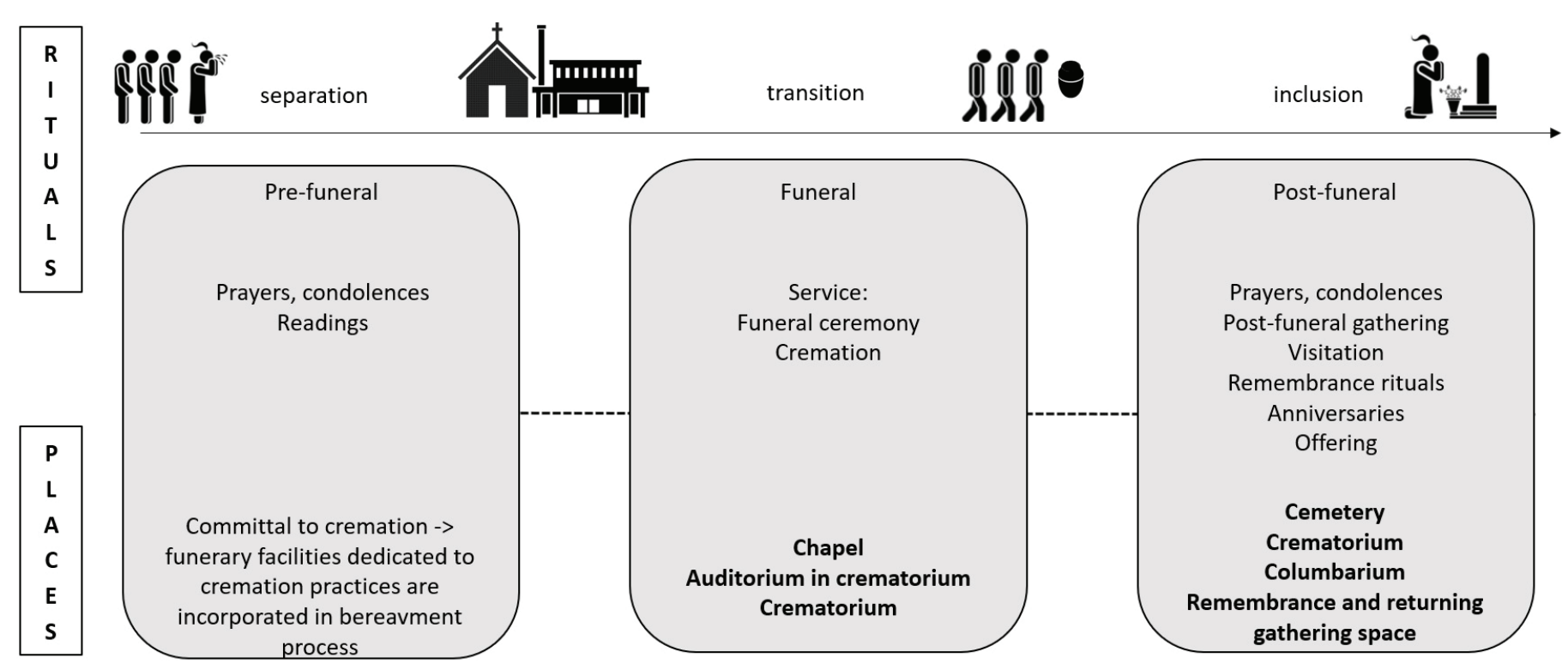

Figure 3.Funerary landscape and its multifaceted nature related to bereavement process and rituals. Own elaboration based on (Keddemann 2011; Pham 2014) 


\begin{tabular}{|c|c|c|c|}
\hline & Form & $\begin{array}{l}\text { The sacred } \\
\text { Religious place: sanctuary, chapel, garden of } \\
\text { remembrance } \\
\text { Garden art }\end{array}$ & $\begin{array}{c}\text { The profane } \\
\text { Functional place: service, suport, industrial facilities } \\
\text { Uniform }\end{array}$ \\
\hline 图国国国 & Activities (Functions) & $\begin{array}{l}\text { Emotional need (private space: loneliness, isolation, } \\
\text { intimacy): } \\
\text { Place for farwell of deceased (ceremony, worship, ritual, } \\
\text { procession) } \\
\text { Place for remembrance (mourning, grieving, } \\
\text { contemplation) } \\
\text { Place for cure (therapy) } \\
\text { Cultural need (public space: gathering, sense of } \\
\text { collective): } \\
\text { Place for extension of social bond (congregation, } \\
\text { community) } \\
\text { Place for tradition inheritance } \\
\text { Place for education }\end{array}$ & $\begin{array}{l}\text { Practical need (utilitarian): } \\
\text { Cremation of bodies } \\
\text { Place for disposal } \\
\text { Administration } \\
\text { Maintenance } \\
\text { Landscaping } \\
\text { Parking } \\
\text { Space saving (ecology, urban planning) }\end{array}$ \\
\hline & Symbolic (Signs) & $\begin{array}{c}\text { Experience of the sacred } \\
\text { Archetypal elements (Eliade, 1957) } \\
\text { Means of artistic expression (interpretation) }\end{array}$ & $\begin{array}{l}\text { Uniform: unadorned surfaces, simple volumes } \\
\text { Function is expressed }\end{array}$ \\
\hline (Functions) & Sense of place & \multicolumn{2}{|c|}{$\begin{array}{c}\text { Proxemic, Identity } \\
\text { Hierarchy - placement } \\
\text { Psychological and spiritual needs (bereavment model) } \\
\text { Mysticism / Utility } \\
\text { Serene / Collective }\end{array}$} \\
\hline
\end{tabular}

Figure 4. Diagram showing the multifaceted landscape for cremation practices (cemetery and crematorium). Own elaboration

In terms of the architectural and landscape arrangements of funerary landscape should have a physical layer - incorporate crematorium, burial space with routing and vegetation. In terms of the phenomenology, funerary landscape should have a semantic layer (sense of place and identity, presence of archetypal design elements) (Eliade 1957; Dee 2001; Hermann 2005) (Figure 4-5). Traditionally, a lot of people found their need of contemplation in religion, but in the contemporary secularised society people try to

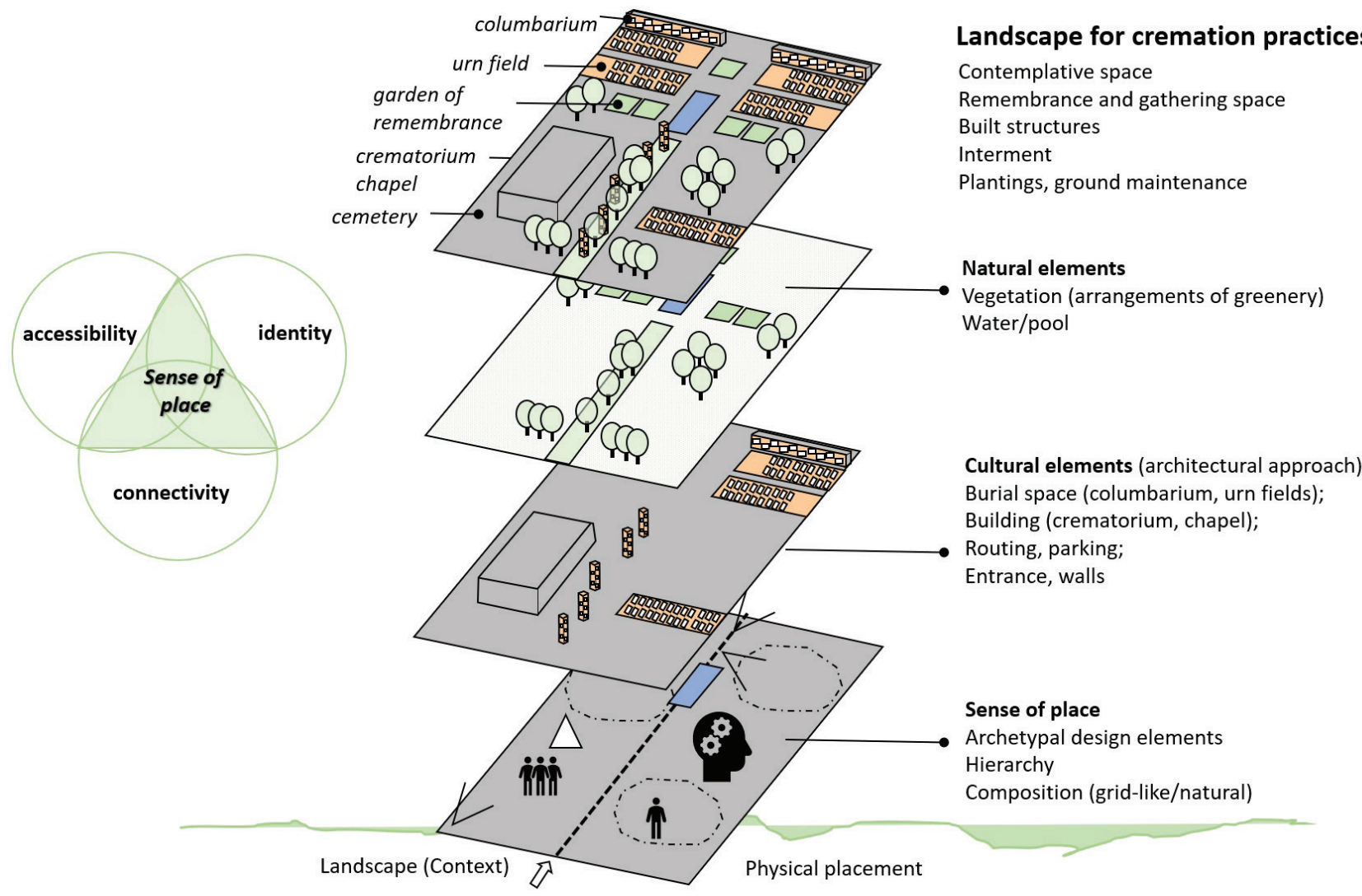

Figure 5. Layers of landscape for cremation practices and burial as a basis for identification of design solutions („,pattern book"). Own elaboration 
find it in other ways and places. That is why important is using means of artistic expression referring to archetypes and universal forms. Archetypal design elements such as: forest sanctuary, thresholds, open air altars, sacred mountain, and axis mundi, speak directly, across distances of time and space, to the human understanding of the temporality and continuity of life, and our essential link to the natural world (Krinke 2005).

Funerary landscape for cremation practices is described as "people-centred", aiming to integrate "spatial elements that interact with people's physiology and psychology" (Chrysikou 2014). That is why, finally four specific landscape themes (layers) regarding multifaceted funerary landscape have been identified: context (physical placement), natural environments, built environments (built structures) and spiritual environments (sense of place). Diagram showing that multifaceted is a basic to identify layers of landscape for cremation practices (Figure 5).

\section{Methodological approach}

\subsection{Research framework}

The process of study went through three stages for answering the research question: How might landscapes be better designed to accommodate increasing cremation practices in Europe? (Figure 6).

\subsubsection{Developing a catalogue of design solutions ("pattern book")}

Cemeteries and crematoria are not simply a form of art. These are places with several functions and socio-cultural meaning. The location of crematoria is often connected to existing cemeteries, because the "cemetery - crematorium" relationship is strong in Europe (Hultquist 2013; Bhatia 2014). The European background was outlined on the basis of research carried out in countries with similar characteristics to Poland in terms of: the dominant religion (i.e. Catholicism), applicable provisions of the cemetery law, index of average population served by 1 crematorium. These criteria were applied in a study of cremation facilities from the following countries: Austria (2 objects), Belgium (8 objects), Denmark (1 site), France (8 objects), Germany (5 objects), Italy (3 objects), Slovakia (1 site), Slovenia (1 site), Sweden ( 2 objects). Finally, 31 objects were covered by the study (Table 3). The facilities designed between 1993 to 2019 were qualified for the research. The choice of the crematoria with modern metrics was determined by the fact that the first crematorium in Poland was opened in 1993 (in Poznań).

Data about crematoria covered by research for the purpose of defining the catalogue of design solutions ("pattern book") were based on the architecture and landscape architecture platforms (archdaily. com; behance.net; dezeen.com; goodbyearchitecture.com; landezine.com). Design solutions were assigned to categories (layers), in accordance with the multifaceted landscape for cremation practices (Figure 5, 7).

Context. When characterizing the context of contemporary crematoria, their placement in relation to cemeteries, interaction with surrounding landscape (visibility of funerary facilities, separation or connection with the surrounding landscape) were taken into account.

\begin{tabular}{|l|l|l|}
\hline Phase & Purpose & Methodology \\
\hline Phase 1 & $\begin{array}{l}\text { Developing a catalogue of design solutions ("pattern book") } \\
\text { on contemporary landscape for cremation practices }\end{array}$ & $\begin{array}{l}\text { Analysis of selected European crematoria (31) in } \\
\text { accordance with the multifaceted criteria }\end{array}$ \\
\hline
\end{tabular}

\begin{tabular}{|l|l|l|}
\hline Phase 2 & $\begin{array}{l}\text { Verifying design solutions in the shaping of the landscape for } \\
\text { cremation practices in Poland }\end{array}$ & $\begin{array}{l}\text { Analysis of selected Polish facilities related to } \\
\text { cremation (39) }\end{array}$ \\
\hline Phase 3 & $\begin{array}{l}\text { Developing the recommendations to strengthen the } \\
\text { multifaceted meaning of landscape for cremation practices }\end{array}$ & $\begin{array}{l}\text { Ordering the design principle in accordance with } \\
\text { the multifaceted criteria of landscape for cremation } \\
\text { practices }\end{array}$ \\
\hline
\end{tabular}

Figure 6. Research flowchart 
Table 3. List of European countries with selected crematoria. Own elaboration

\begin{tabular}{|c|c|c|c|c|c|c|c|c|}
\hline \multirow[t]{2}{*}{ Country } & \multirow[t]{2}{*}{ Dominant religion } & \multirow{2}{*}{$\begin{array}{l}\text { Crema- } \\
\text { tion rate } \\
{[\%]}\end{array}$} & \multirow{2}{*}{$\begin{array}{l}\text { Number of } \\
\text { active cre- } \\
\text { matoria }\end{array}$} & \multirow{2}{*}{$\begin{array}{l}\text { Population } \\
\text { / } 1 \\
\text { crematorium }\end{array}$} & \multirow{2}{*}{$\begin{array}{l}\text { Scattering } \\
\text { ashes } \\
\text { authorised } \\
\text { by law }\end{array}$} & \multirow{2}{*}{$\begin{array}{l}\text { Obligation } \\
\text { to deposit } \\
\text { a cremated } \\
\text { corps in the } \\
\text { cemetery } \\
\end{array}$} & \multicolumn{2}{|c|}{ Crematoria selected for research } \\
\hline & & & & & & & $\begin{array}{l}\text { Location (year of con- } \\
\text { struction) }\end{array}$ & $\begin{array}{l}\text { Num- } \\
\text { ber }\end{array}$ \\
\hline Austria & Catholicism (63\%) & 44.6 & 16 & 678615 & $+*$ & - & $\begin{array}{l}\text { Linz (2003) } \\
\text { Kalsdorf (2018) }\end{array}$ & 2 \\
\hline Belgium & $\begin{array}{l}\text { Catholicism }(62 \%) \\
\text { No religion }(29 \%)\end{array}$ & 62.0 & 17 & 655970 & + & - & $\begin{array}{l}\text { Heimolen (2008) } \\
\text { Frasnes-lez-Anvaing } \\
\text { (2010) } \\
\text { Uitzicht (2011) } \\
\text { Court-Saint-Étienne } \\
\text { (2011) } \\
\text { Hofheide (2013) } \\
\text { Daelhof Zemst (2015) } \\
\text { Stuifduin Lommel (2018) } \\
\text { Aalst, Siesegem (2019) }\end{array}$ & 8 \\
\hline Denmark & Lutheranism (79\%) & 83.9 & 20 & 283917 & $+*$ & - & Faelles Ringsted (2013) & 1 \\
\hline France & $\begin{array}{l}\text { Catholicism (60\%) } \\
\text { No religion (28\%) }\end{array}$ & 39.5 & 172 & 385569 & $+*$ & - & Faelles Ringsted (2013) & 8 \\
\hline Germany & $\begin{array}{l}\text { No religion (33\%) } \\
\text { Catholicism (29\%) }\end{array}$ & 67.0 & 158 & 513157 & + & + & $\begin{array}{l}\text { Rhein-Taunus (1999) } \\
\text { Kassel }(1927,2000) \\
\text { Berlin-Treptow (2001) } \\
\text { Fürstenzell (2004) } \\
\text { Villingen-Schwenningen } \\
\text { (2018) }\end{array}$ & 5 \\
\hline Italy & Catholicism (87\%) & 23.9 & 70 & 868402 & + & - & $\begin{array}{l}\text { Tempio di Cremazione, } \\
\text { Parma (2009) } \\
\text { Copparo (2014) } \\
\text { Rimini (2016) }\end{array}$ & 3 \\
\hline Slovakia & Catholicism (62\%) & No data & 4 & 1799012 & + & + & Levice (2018) & 1 \\
\hline Slovenia & Catholicism (74\%) & 83.9 & 2 & 1044500 & + & + & Maribor (1998) & 1 \\
\hline Sweden & $\begin{array}{l}\text { Protestantism } \\
(67 \%)\end{array}$ & 82.1 & 66 & 151706 & $+*$ & $+^{*}$ & $\begin{array}{l}\text { New Woodland Crema- } \\
\text { torium }(2013) \\
\text { Kalmar }(1963,2013)\end{array}$ & 2 \\
\hline Poland & Catholicism (92\%) & $24.0 * *$ & 63 & 620223 & - & + & (Table 4) & 39 \\
\hline
\end{tabular}

* possible if legally defined conditions are met

** last published data for 2016; in light of the law in force in Poland, private crematoria are not obliged to provide information on the number of cremations carried out; they are considered the business entities

Natural space. It was assessed, whether the vegetation used in funerary places arrangement is diverse, adapted to land form and based on native plants, integrated with existing site features.

Built space. According to Wylie (2007) the task was to describe the morphology (articulation, means of artistic expression) - the shape, material, colour, scale of a contemporary landscape dedicated to cremation, and in so doing to reveal the characteristics of the human culture in the aspect of death perception. Moreover, programmatic elements: burial space (spatial solutions dedicated to cremation), routing (transportation system), structure (organization of space) were identified. It was also assessed whether the creation of a physical setting allows people to use the funerary landscape unimpeded (accessibility).

Sense of place. It was assessed a spiritual connectedness of place to context, of nature and human-made structures. Because a crematorium is a religious facility, when conducting the field research, the attention was paid to the arrangement of the building's surroundings and the identification of archetypal design elements (Moon 1991; Ronnberg and Mar- 


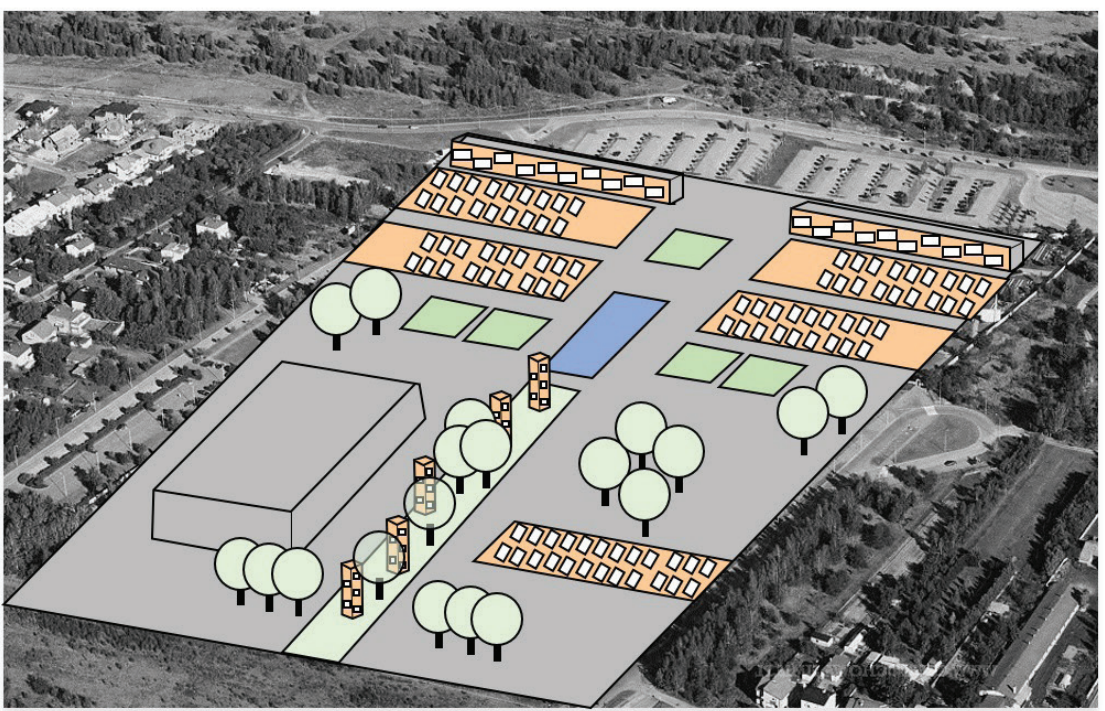

\section{Context}

- Location (Physical placement)

- Interaction with the landscape (connection, separation?)

- Crematorium and burial space (cemetery) relations

Natural elements (use of existing landscape) - Arrangements of greenery/plantings

- Natural features (landform, water etc.)

\section{Cultural elements}

- Architecture of crematorium, chapel

- Columbarium and other spaces dedicated to depositing the human ashes

- Entrance, fence and other man-made elements of development

\section{- Sense of place}

- Archetypal (sacred) design elements

- Composition

- Structure and program

Figure 7. Four layers of multifaceted landscape as a basis for identification of design solutions. Own elaboration

tin 2010), for instance: sacred graves - trees (Welch and Parry 2011), mountain, water (Eliade 1957) and specific spatial qualities - sacred composition: paths, boundary, foci (a form that marks a place of sacred significance), thresholds (an entrance place or gateway), view foreground (Dee 2001; Hermann 2005). It was also described composition of funerary landscape (appearance of the landmarks, iconic elements, human-made landscape and natural, placed within a pre-existing landscape). The cemetery-crematorium relationship was also examined. By ana- lysing the development and spatial composition of European funeral landscapes for cremation practices selected for the research, the role of the crematorium in the composition and structuring of the cemetery space was defined.

\subsubsection{Verifying design solutions in the shaping of the landscape for cremation practices in Poland}

The next stage of the research was to verify whether design solution ("pattern book"), which were identified by analysing the 31 European crematoria, were
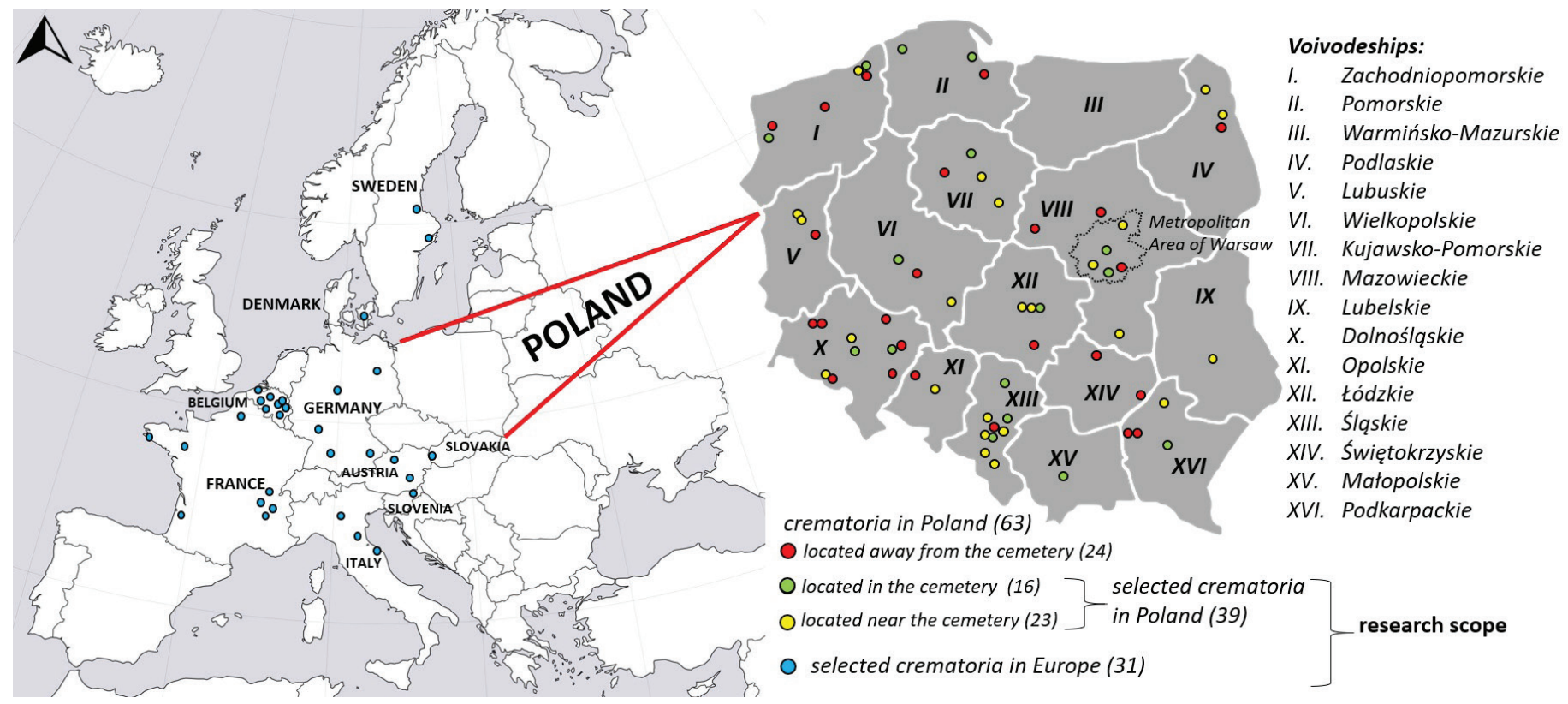

Figure 8. Research scope from Europe (31 objects) and Poland (39 objects). Own elaboration 
Table 4. List of crematoria in Poland by voivodeships. Own elaboration

\begin{tabular}{|c|c|c|}
\hline $\begin{array}{l}\text { Voivodeship (number of } \\
\text { crematoria) }\end{array}$ & $\begin{array}{l}\text { RESEARCH SCOPE ( } 39 \text { OBJECTS) } \\
\text { Crematoria developed at/next to existing cemeteries }\end{array}$ & Separated crematoria (24 OBJECTS) \\
\hline Dolnośląskie (10) & $\begin{array}{l}\text { 1. Jelenia Góra „Anubis”; } \\
\text { 2. Jaszków } \\
\text { 3. Lubin “Leonardo” } \\
\text { 4. Wrocław - Psie Pole }\end{array}$ & $\begin{array}{l}\text { Głogów „Krematorium Polska”; Głogów } \\
\text { „Cremering”; Garbce „Crem Mark”; } \\
\text { Jelenia Góra „Koroner”; Strzelin „Olimp”; } \\
\text { Wrocław „Gloria” - Oporów }\end{array}$ \\
\hline Kujawsko-Pomorskie (4) & $\begin{array}{l}\text { 5. Nowa Chełmża „Fenix" } \\
\text { 6. Włocławek „Tartar” } \\
\text { 7. Toruń }\end{array}$ & Białe Błota \\
\hline Lubelskie (1) & 8. Czerniejów & - \\
\hline Lubuskie (3) & $\begin{array}{l}\text { 9. Gorzów Wlkp. „Products” } \\
\text { 10. Gorzów Wlkp. „Gorzowski Dom Pogrzebowy” }\end{array}$ & Skwierzyna „Caelum” \\
\hline Łódzkie (4) & $\begin{array}{l}\text { 11. Łódź „Klepsydra” } \\
\text { 12. Łódź, Zakładowa Street } \\
\text { 13. Łódź, Żyzna Street }\end{array}$ & Bełchatów „Carcadia” \\
\hline Małopolskie (1) & 14. Kraków „Klepsydra” (cemetery under construction) & - \\
\hline Mazowieckie (8) & $\begin{array}{l}\text { 15. Antoninów } \\
\text { 16. Pruszków } \\
\text { 17. Radom „Zakres” } \\
\text { 18. Warszawa } \\
\text { 19. Wyszków }\end{array}$ & $\begin{array}{l}\text { Otwock „Exitus”; Nowe Trzepowo; Przas- } \\
\text { nysz - Sierakowo }\end{array}$ \\
\hline Opolskie (2) & 20. Opole & Skarbimierz „Brzeg” \\
\hline Podkarpackie (3) & $\begin{array}{l}\text { 21. Rzeszów } \\
\text { 22. Stalowa Wola „Memento” }\end{array}$ & $\begin{array}{l}\text { Mielec „Charon” } \\
\text { Mielec „Eden” }\end{array}$ \\
\hline Podlaskie (3) & $\begin{array}{l}\text { 23. Karakule } \\
\text { 24. Suwałki }\end{array}$ & Białystok \\
\hline Pomorskie (3) & $\begin{array}{l}\text { 25. Gdańsk „Zieleń” } \\
\text { 26. Słupsk }\end{array}$ & Roszkowo „Pruszcz Gdański” \\
\hline Śląskie (9) & $\begin{array}{l}\text { 27. Częstochowa } \\
\text { 28. Bytom } \\
\text { 29. Dąbrowa Górnicza „Aurora” } \\
\text { 30. Jasienica } \\
\text { 31. Katowice „Dom Pożegnań” } \\
\text { 32. Ruda Śląska „Park Pamięci” } \\
\text { 33. Ruda Śląska - Wirek } \\
\text { 34. Żory „Sacrum. Pamięć i Popiół” }\end{array}$ & Chorzów \\
\hline Świętokrzyskie (2) & - & $\begin{array}{l}\text { Sandomierz; Skarżysko-Kamienna "Cen- } \\
\text { trum Necropolis" }\end{array}$ \\
\hline Warmińsko-Mazurskie (0) & - & - \\
\hline Wielkopolskie (3) & $\begin{array}{l}\text { 35. Poznań „Universum” } \\
\text { 36. Kalisz „Kremulus” }\end{array}$ & Środa Wielkopolska "Finis" \\
\hline Zachodniopomorskie (6) & $\begin{array}{l}\text { 37. Koszalin, Gnieźnieńska Street } \\
\text { 38. Koszalin „Atena” } \\
\text { 39. Szczecin }\end{array}$ & $\begin{array}{l}\text { Koszalin, ul. Różana; Police „Ku Słońcu”; } \\
\text { Ramlewo „Weles” }\end{array}$ \\
\hline
\end{tabular}

used in contemporary Polish facilities related to cremation. The research covered 39 crematoria located in or next to existing cemeteries (Table 4).
Based on a source query, field vision carried out in July and August 2019 crematoria were identified in terms of multifaceted landscape for cremation practices layers (Figure 7). Each sub-criterion (design 
solution) has been evaluated by using the scores of: 1 (presence), 0.5 (moderate presence), and 0 (absence).

\section{Results}

\subsection{Design solutions identified in contemporary European landscape for cremation practices}

As a result of the literature review and research on 31 European objects a list of design solutions worth applying in contemporary funerary landscape was developed, which are presented in Table 5 below.

Context. Research shows that area predestinated for funerary rituals are well wooded piece of ground (e.g. Rhein-Taunus, Berlin) or westlands (e.g. Parma, Frasnes-les-Anvaing) with natural undulations and good views. Attractive land form goes along with easy access by public transport and by private car (the site is well suited for the building, and is accessible by communication), (the creation of a physical setting that allows people to use the space unimpeded). That is why, the crematorium is so sited that its use does not have any material, negative effect on the neighbourhood - it is integrated with cultural landscape, it is a part of everyday life. The spatial form of the crematorium strongly results from the local natural and landscape conditions (topography, local construction material). The façades of the Italian "Temple of Cremation" (Tempio di Cremazione) were finished with light brick. After all, the province of Parma has deeply rooted tradition of using clay as a building material. It can be seen that over the 20th and 21st centuries, the monumental architecture of the crematorium is giving way to horizontal composition (e.g. Heimolen, Hofheide, Uitzicht).

Natural space. Research shows that vegetation is an essential element of the funerary landscape arrangement. A small garden (patio, courtyard arranged with greenery or intimate enclosure) closely adjoining the crematory building is usually provided as an enclosed retreat for quiet thought and contemplation.

Table 5. List of design solutions identified during the research of European crematoria (divided into the layers in accordance with the model in Figure 5, 7). Own elaboration

\begin{tabular}{|c|c|c|c|c|}
\hline $\begin{array}{l}\text { Multifaceted } \\
\text { landscape layer }\end{array}$ & Item & Design solution & Description & $\begin{array}{l}\text { Examples of facilities imple- } \\
\text { menting the solution }\end{array}$ \\
\hline \multirow[t]{5}{*}{ CONTEXT } & \multirow[t]{2}{*}{1} & \multirow{2}{*}{$\begin{array}{l}\text { Interaction } \\
\text { with landscape } \\
\text { (funerary place } \\
\text { as a part of } \\
\text { surrounding } \\
\text { landscape) }\end{array}$} & $\begin{array}{l}\text { Public memorial landscape. Crematorium as } \\
\text { a landmark, natural component of the land- } \\
\text { scape surrounding, visible (good exposition } \\
\text { zone) - open design }\end{array}$ & Kalsdorf (AUT), Hofheide (BE) \\
\hline & & & $\begin{array}{l}\text { Private memorial landscape, invisible (with- } \\
\text { in woodland areas). Crematorium integrated } \\
\text { with natural morphology, vegetation: hori- } \\
\text { zontal building shape (long, low in human } \\
\text { scale) hidden with landform }\end{array}$ & $\begin{array}{l}\text { Aalst (BE), Frasnes-lez-Anvaing } \\
\text { (BE), Berlin (GER), Uitzicht (BE), } \\
\text { Lommel (BE), Rhein-Taunus } \\
\text { (GER), Ringsted (DK), Kalmar } \\
\text { (SWE), Court-Saint-Étienne (BE) }\end{array}$ \\
\hline & \multirow[t]{3}{*}{2} & \multirow[t]{3}{*}{$\begin{array}{l}\text { Crematorium } \\
\text { and interment } \\
\text { space relation }\end{array}$} & $\begin{array}{l}\text { Crematorium is developed next to existing } \\
\text { cemetery (integrate the crematorium into } \\
\text { the existing cemetery) }\end{array}$ & $\begin{array}{l}\text { Quimper (FR), Montmartre (FR), } \\
\text { Lommel (BE), Copparo (IT), Linz } \\
\text { (AUT) }\end{array}$ \\
\hline & & & $\begin{array}{l}\text { Crematorium at existing cemetery (as a com- } \\
\text { ponent of cemetery composition) }\end{array}$ & $\begin{array}{l}\text { Heimolen (BE), Berlin (GER), } \\
\text { Rhein-Taunus (GER), Kassel (GER), } \\
\text { Court-Saint-Étienne (BE) }\end{array}$ \\
\hline & & & $\begin{array}{l}\text { Separate crematorium. Crematorium is not } \\
\text { connected to a (existing) cemetery but there } \\
\text { is garden of remembrance (fr. le jardin du } \\
\text { souvenir) }\end{array}$ & $\begin{array}{l}\text { Valence (FR), Montélimar (FR), } \\
\text { Biganos (FR), Amiens (FR), Ring- } \\
\text { sted (DK) }\end{array}$ \\
\hline $\begin{array}{l}\text { NATURAL SPACE } \\
\text { (LANDSCAPE } \\
\text { ARTICULATION) }\end{array}$ & 3 & $\begin{array}{l}\text { Vegetation } \\
\text { arrangement }\end{array}$ & $\begin{array}{l}\text { Formal arrangement of landscape with di- } \\
\text { verse vegetation (spatial order based on cir- } \\
\text { cles and squares - grid-like arrangement) }\end{array}$ & $\begin{array}{l}\text { Linz (AUT), Frasnes-les-Anvaing } \\
(F R)\end{array}$ \\
\hline
\end{tabular}




\begin{tabular}{|c|c|c|c|c|}
\hline $\begin{array}{l}\text { NATURAL SPACE } \\
\text { (LANDSCAPE } \\
\text { ARTICULATION) }\end{array}$ & 3 & $\begin{array}{l}\text { Vegetation } \\
\text { arrangement }\end{array}$ & $\begin{array}{l}\text { Morphological, natural landscape with di- } \\
\text { verse vegetation (trees, shrubs, meadows), } \\
\text { park-like grounds around the crematorium } \\
\text { (natural arrangement placed within a pre-ex- } \\
\text { isting landscape) }\end{array}$ & $\begin{array}{l}\text { Fürstenzell (GER), Aalst (BE), Hof- } \\
\text { heide (BE), Lommel (BE), Rhein- } \\
\text { Taunus (GER), Court-Saint-Éti- } \\
\text { enne (BE) }\end{array}$ \\
\hline \multirow{4}{*}{$\begin{array}{l}\text { BUILT SPACE } \\
\text { (ARCHITECTURAL } \\
\text { ARTICULATION) } \\
\text { Architectural, } \\
\text { artistic means of } \\
\text { expression }\end{array}$} & 4 & Shape & $\begin{array}{l}\text { Simple (minimalistic box - simple volumes), } \\
\text { linearity, rhythmic, plain surfaces, unadorned } \\
\text { surfaces }\end{array}$ & $\begin{array}{l}\text { Aalst (BE), Lommel (BE), Parma } \\
\text { (IT), Copparo (IT), Heimolen (BE), } \\
\text { Levice (SK), Kalmar (SWE), Court- } \\
\text { Saint-Étienne (BE), Kassel (GER) }\end{array}$ \\
\hline & 5 & Fabric & $\begin{array}{l}\text { Transparent building: large window, glass } \\
\text { walls; vernacular architecture (brick, wood, } \\
\text { stone) }\end{array}$ & $\begin{array}{l}\text { Heimolen (BE), Biganos (FR), } \\
\text { Parma (IT), Levice (SK), Kalmar } \\
\text { (SWE), Court-Saint-Étienne (BE), } \\
\text { Kassel (GER) }\end{array}$ \\
\hline & 6 & Colourscape & $\begin{array}{l}\text { Camouflage architecture. Gray, beige, brown, } \\
\text { orange (corten steel) reference to the colours } \\
\text { of the earth and nature ("Earth to earth, ash- } \\
\text { es to ashes, dust to dust") }\end{array}$ & $\begin{array}{l}\text { Lommel (BE), Hofheide (BE), } \\
\text { Copparo (IT), Kalmar (SWE), } \\
\text { Court-Saint-Étienne (BE) }\end{array}$ \\
\hline & 7 & Light & $\begin{array}{l}\text { Light and darkness, perforation of the ceiling, } \\
\text { walls, natural light, dramatic lighting (objects } \\
\text { of contemplation) }\end{array}$ & $\begin{array}{l}\text { Lommel (BE), Heimolen (BE), } \\
\text { Court-Saint-Étienne (BE), Kassel } \\
\text { (GER) }\end{array}$ \\
\hline \multirow[t]{5}{*}{$\begin{array}{l}\text { PROGRAMMATIC } \\
\text { ELEMENTS }\end{array}$} & 8 & Burial space & $\begin{array}{l}\text { Multiple choices (options for the cremated } \\
\text { body): scattering field, urn field (urn garden), } \\
\text { columbarium }\end{array}$ & $\begin{array}{l}\text { Kalsdorf (AUT), Hofheide (BE), } \\
\text { Heimolen (BE), Uitzicht (BE), } \\
\text { Rhein-Taunus (GER) }\end{array}$ \\
\hline & 9 & $\begin{array}{l}\text { Structure } \\
\text { (social) }\end{array}$ & $\begin{array}{l}\text { Variety of space (intimate space and public } \\
\text { space): open courtyard and enclosed patios } \\
\text { ensure security from the outside world (con- } \\
\text { templative space with decorative paving pat- } \\
\text { tern, sacred grave, trees), linkage between } \\
\text { the smallest part to the whole in a harmoni- } \\
\text { ous balance (connectivity) }\end{array}$ & $\begin{array}{l}\text { Copparo (IT), Lommel (BE), Hei- } \\
\text { molen (BE), Hofheide (BE), Court- } \\
\text { Saint-Étienne (BE) }\end{array}$ \\
\hline & 10 & $\begin{array}{l}\text { Structure } \\
\text { (organization) }\end{array}$ & $\begin{array}{l}\text { Symmetrical organization of crematorium ar- } \\
\text { rival zone versus park-like free organization } \\
\text { of burial space (architectural and landscape } \\
\text { promenade) }\end{array}$ & $\begin{array}{l}\text { Fürstenzell (GER), Heimolen (BE), } \\
\text { Aalst (BE) }\end{array}$ \\
\hline & 11 & Parking plots & $\begin{array}{l}\text { Large area dedicated to parking space (acces- } \\
\text { sibility) }\end{array}$ & $\begin{array}{l}\text { Aalst (BE), Court-Saint-Étienne } \\
(\mathrm{BE})\end{array}$ \\
\hline & 12 & $\begin{array}{l}\text { Routing } \\
\text { (Transportation } \\
\text { system) }\end{array}$ & $\begin{array}{l}\text { Distinction between primary, secondary and } \\
\text { tertiary paths (crematorium is reachable by } \\
\text { primary paths, the spaces for cremated bod- } \\
\text { ies are reachable by secondary and tertiary } \\
\text { paths) (accessibility) }\end{array}$ & $\begin{array}{l}\text { Fürstenzell (GER), Aalst (BE), } \\
\text { Lommel (BE) }\end{array}$ \\
\hline \multirow[t]{2}{*}{ SENSE OF PLACE } & 13 & $\begin{array}{l}\text { Archetypal } \\
\text { design } \\
\text { elements }\end{array}$ & $\begin{array}{l}\text { Complete sacred landscape: essence of wa- } \\
\text { ter (pond, stream, impluvium), mountain, sa- } \\
\text { cred groves - trees, emptiness (path) }\end{array}$ & $\begin{array}{l}\text { Fürstenzell (GER), Heimolen (BE), } \\
\text { Hofheide (BE), Beaurepaire (FR), } \\
\text { Biganos (FR), Ringsted (DK), Dael- } \\
\text { hof (BE), Lommel (BE), Aalst (BE) }\end{array}$ \\
\hline & 14 & Composition & $\begin{array}{l}\text { Universal symbol (the circle, square) as a ba- } \\
\text { sis for the deathscape arrangement } \\
\text { Centralized space (crematorium on the main } \\
\text { axis); path, entrance (arrival zone), thresh- } \\
\text { olds, foci } \\
\text { Funerary places as a landmarks or iconic ele- } \\
\text { ments (identity) }\end{array}$ & $\begin{array}{l}\text { Amiens (FR), Biganos (FR), Va- } \\
\text { lence (FR) }\end{array}$ \\
\hline
\end{tabular}


Built space. The main assumption of funerary landscape is the architectural and landscape promenade as a series of experiences that have been designed to address the phases in the integrated bereavement model. There is the entrance, buildings of crematorium complex (chapel, crematorium, maintenance building, for employees, equipment and management, waiting and gathering spaces) and walkways, linkages with cemetery, columbaria, and remembrance spaces. The entrance of the funerary place is visible, findable and reachable for cars, buses, cyclists and walkers (accessibility). Covered entryways and porte-cocheres provide sheltering space to pause and gather before entering the complex and leaving the world behind. The parking lot can accommodate many cars. There is also place for bicycles. In the 20th and 21st centuries, the convention for masking crematorium chimneys is developing by introducing columns, panels in the facade of buildings that are the architectural equivalent of trees (e.g. Biganos, Hofheide, Lommel), which is also noted by Laqueur (2015). Researched facilities are characterized by neutrality (pure, neutral architecture), tranquillity. The plain materials contribute to the simplicity of the design and make it symbolically neutral. The building is not a church or chapel nor a house but sober and righteous object. Devoid of any symbolic ornamentation allowing the crematorium and its surrounding to be used by people of all faiths (cultural, perceptual, ethnic accessibility). Architecture of contemporary European crematoria are notable building that communicate to the surrounding landscape.

Sense of place. From the cultural point of view, an important role play funerary landscape boundaries. Visibility in the landscape is provided by a fence, which creates boundaries between polluted and unpolluted space, or between secular and religious space (Worpole 2003, p. 71). Crematorium is the landmark and is located in the centre or via the main axis of the cemetery (e.g. Berlin-Treptow, Hofheide, Beaurepaire) or in the composition, it plays the role of an introductory gate to the system, because it is located at the main entering of the cemetery - arrival zone (e.g. Heimolen, Quimper, Uitzicht). Path and main axis symbolically express the idea of the journey. The idea of the road is a symbol of a pilgrim, who leads his journey to the final farewell (Barrie,
1996) (in the case of the deceased, it is a symbolic farewell to the world of the living, and in the case of mourners - a farewell to a loved one). In many of the analysed implementations, the motif of emptiness is used as a distance, retardation zone, viewing field allowing temporary isolation, silencing and preparation for the transition from the profane to the sacred zone, e.g. Parma, Heimolen, Hofheide. This threshold serves as an important dramatic moment of entry in which the visitor crosses from the outside into the sacred space, beginning the first architectural ritual sequence. In the analysed facilities, the emanation of the sacred mountain (mountain represents the bond between heaven and earth, symbolizes the universal axis pattern, the centre of the world, the seat of gods and the place of transformation; in the Slavic, Germanic and Celtic peoples, the mountains were the land of the souls of dead) is the crematorium building, located in the centre of spatial assumption, e.g. Berlin, Heimolen. Adolf Loos said that "when we find a mound in the woods (...) raised to a pyramidal form by means of a spade, we become serious and something in us says: someone was buried here" (Worpole 2003, p. 7). Often, to emphasize the architecture of the building, the so-called landscape frame of tall greenery (sacred groves - tree archetype) constituting a counterpoint for the building body and the colour of its façade, is introduced. An important element of the crematorium surroundings arrangement in Europe is a water reservoir (emanation of the holy water), e.g. Beaurepaire, Daelhof, Fürstenzell, Heimolen, Hofheide, Ringsted. The element of water plays an important role in the Christian funeral rite. "In the context of the biblical flood-story and the water shedding out of Christ's wounds on the cross, a combination of the dreadful and even deadly powers of water with its life-giving qualities come to the fore. The element of water and its many symbolic meanings is also universal and bears different meanings from an anthropological point of view, open to other religions and cultures" (Goyvaerts and Vande Keere 2020, p. 10).

\subsection{Contemporary funeral landscape for cremation practices in Poland and design solutions}

The verification of the sub-criteria showed that, currently, a few design solutions commonly used in Eu- 
Table 6. Verification of design solutions in the selected contemporary funeral places in Poland (crematoria located in/next to existing cemeteries), where each sub-criterion (design solution) has been evaluated by using the scores of 1 (presence), 0.5 (moderate presence), and 0 (absence). Own elaboration

\begin{tabular}{|c|c|c|c|c|c|c|c|c|c|c|c|c|c|c|c|}
\hline \multirow{3}{*}{$\begin{array}{l}\text { Number } \\
\text { of } \\
\text { objects } \\
\text { (Table 2) }\end{array}$} & \multicolumn{14}{|c|}{ Layers of funeral landscape for cremation practices } & \multirow[t]{3}{*}{$\Sigma$} \\
\hline & \multicolumn{2}{|c|}{ Context } & \multirow{2}{*}{\begin{tabular}{|l|}
$\begin{array}{l}\text { Natural } \\
\text { space }\end{array}$ \\
3 \\
\end{tabular}} & \multicolumn{4}{|c|}{$\begin{array}{l}\text { Built space (architectural } \\
\text { approach) }\end{array}$} & \multicolumn{5}{|c|}{ Built space (programmatic) } & \multicolumn{2}{|c|}{$\begin{array}{l}\text { Sense of } \\
\text { place }\end{array}$} & \\
\hline & 1 & 2 & & 4 & 5 & 6 & 7 & 8 & 9 & 10 & 11 & 12 & 13 & 14 & \\
\hline 1. & 0.5 & 0.5 & 0 & 1 & 0.5 & 0.5 & 0.5 & 0 & 0 & 0 & 1 & 0 & 0 & 0 & 4.5 \\
\hline 2. & 0.5 & 1 & 0 & 0 & 0.5 & 1 & 0 & 1 & 0.5 & 0.5 & 1 & 1 & 0 & 0.5 & 7.5 \\
\hline 3. & 1 & 0.5 & 0 & 1 & 0.5 & 0.5 & 0 & 0 & 0 & 0.5 & 1 & 1 & 0 & 0.5 & 6.5 \\
\hline 4. & 1 & 1 & 1 & 0.5 & 1 & 1 & 0.5 & 1 & 1 & 1 & 1 & 1 & 0.5 & 1 & 12.5 \\
\hline 5. & 0.5 & 0.5 & 0 & 1 & 0 & 0.5 & 0 & 0 & 0 & 0 & 0 & 0 & 0 & 0 & 2.5 \\
\hline 6. & 0 & 0 & 0 & 1 & 1 & 1 & 1 & 0 & 0 & 0 & 0 & 0 & 0 & 0 & 4.0 \\
\hline 7. & 0.5 & 0.5 & 0.5 & 1 & 1 & 1 & 1 & 0 & 0 & 0 & 0.5 & 0.5 & 0 & 0 & 6.5 \\
\hline 8. & 0.5 & 0.5 & 0 & 0 & 0 & 0 & 0 & 0 & 0 & 0 & 0.5 & 0.5 & 0 & 0 & 2.0 \\
\hline 9. & 1 & 1 & 1 & 1 & 1 & 1 & 1 & 0.5 & 1 & 1 & 1 & 1 & 0.5 & 0.5 & 12.5 \\
\hline 10. & 0.5 & 0.5 & 0 & 1 & 0.5 & 0.5 & 0.5 & 0 & 0 & 0 & 1 & 0.5 & 0 & 0 & 5.0 \\
\hline 11. & 0.5 & 0.5 & 0.5 & 1 & 1 & 1 & 1 & 0 & 0.5 & 0 & 0 & 0 & 0 & 0 & 6.0 \\
\hline 12. & 0.5 & 1 & 0.5 & 0.5 & 0 & 0 & 0 & 1 & 1 & 0.5 & 1 & 1 & 0 & 0.5 & 7.5 \\
\hline 13. & 0 & 0.5 & 0 & 0.5 & 0 & 0 & 0 & 0 & 0 & 0 & 0.5 & 0 & 0 & 0 & 1.5 \\
\hline 14. & 1 & 1 & 0.5 & 1 & 1 & 1 & 0.5 & 1 & 0.5 & 1 & 1 & 1 & 0 & 1 & 11.5 \\
\hline 15. & 1 & 1 & 1 & 1 & 1 & 1 & 1 & 1 & 1 & 1 & 1 & 1 & 1 & 1 & 14.0 \\
\hline 16. & 0 & 0.5 & 0.5 & 0 & 0 & 0 & 0 & 0 & 0 & 0 & 1 & 0 & 0 & 0 & 2.0 \\
\hline 17. & 0.5 & 0.5 & 0.5 & 1 & 1 & 1 & 1 & 0 & 0.5 & 0 & 1 & 0.5 & 0 & 0.5 & 8.0 \\
\hline 18. & 1 & 1 & 1 & 0.5 & 0 & 0.5 & 0.5 & 1 & 1 & 1 & 1 & 1 & 0.5 & 1 & 11.0 \\
\hline 19. & 0.5 & 0.5 & 0.5 & 0 & 0 & 0 & 0 & 0 & 0 & 0 & 1 & 0 & 0 & 0 & 2.5 \\
\hline 20. & 0.5 & 0.5 & 0.5 & 1 & 0 & 1 & 0 & 0.5 & 1 & 0.5 & 0.5 & 1 & 0 & 0 & 7.0 \\
\hline 21. & 1 & 1 & 1 & 1 & 0.5 & 0 & 0.5 & 1 & 1 & 1 & 1 & 1 & 0.5 & 1 & 11.5 \\
\hline 22. & 1 & 1 & 0.5 & 1 & 0.5 & 0.5 & 0.5 & 0 & 0.5 & 0.5 & 0.5 & 1 & 0 & 0.5 & 8.0 \\
\hline 23. & 1 & 0.5 & 0 & 1 & 0 & 0.5 & 0.5 & 0 & 0 & 0.5 & 1 & 1 & 0 & 0.5 & 6.5 \\
\hline 24. & 1 & 0.5 & 0 & 0 & 0 & 0 & 0 & 0.5 & 0 & 0.5 & 1 & 1 & 0 & 0 & 4.5 \\
\hline 25. & 1 & 1 & 1 & 1 & 0 & 0.5 & 0 & 1 & 1 & 1 & 1 & 1 & 0.5 & 1 & 11.0 \\
\hline 26. & 1 & 0.5 & 0.5 & 0 & 0 & 0.5 & 1 & 0.5 & 0.5 & 0 & 1 & 0.5 & 0 & 0 & 6.0 \\
\hline 27. & 1 & 1 & 1 & 1 & 1 & 1 & 0.5 & 1 & 1 & 1 & 1 & 1 & 0.5 & 1 & 13.0 \\
\hline 28. & 1 & 1 & 1 & 0 & 1 & 1 & 0 & 0 & 1 & 0 & 0 & 0.5 & 0.5 & 0 & 7.0 \\
\hline 29. & 0.5 & 1 & 0 & 1 & 0.5 & 1 & 0.5 & 0 & 0 & 0.5 & 0.5 & 0.5 & 0.5 & 0.5 & 7.0 \\
\hline 30. & 0.5 & 1 & 0.5 & 0 & 0 & 0 & 0 & 0 & 0.5 & 0 & 0.5 & 0 & 0.5 & 0 & 3.5 \\
\hline 31. & 1 & 1 & 0.5 & 1 & 1 & 1 & 1 & 0 & 0 & 0 & 0.5 & 0.5 & 1 & 0.5 & 8.5 \\
\hline 32. & 1 & 1 & 1 & 0.5 & 0.5 & 0.5 & 0.5 & 1 & 1 & 1 & 1 & 1 & 0.5 & 1 & 11.5 \\
\hline 33. & 1 & 0.5 & 0 & 1 & 0.5 & 0.5 & 1 & 0 & 0 & 0.5 & 0.5 & 0 & 0 & 0 & 5.5 \\
\hline 34. & 1 & 1 & 0.5 & 1 & 1 & 1 & 1 & 1 & 0.5 & 1 & 1 & 1 & 0 & 0.5 & 11.5 \\
\hline 35. & 1 & 1 & 1 & 0.5 & 1 & 1 & 0 & 1 & 1 & 0.5 & 0.5 & 1 & 0 & 0 & 9.5 \\
\hline 36. & 0.5 & 1 & 0.5 & 0 & 0 & 0 & 0.5 & 1 & 0.5 & 0.5 & 1 & 1 & 0 & 0.5 & 7.0 \\
\hline 37. & 0.5 & 1 & 1 & 1 & 0.5 & 0.5 & 0.5 & 1 & 0.5 & 1 & 1 & 1 & 0.5 & 0.5 & 10.5 \\
\hline 38. & 0 & 0.5 & 0 & 0.5 & 0.5 & 0.5 & 0 & 0 & 0 & 0 & 0.5 & 0 & 0 & 0 & 2.5 \\
\hline 39. & 1 & 1 & 1 & 0.5 & 0.5 & 0.5 & 0 & 1 & 1 & 1 & 1 & 1 & 1 & 1 & 11.5 \\
\hline$\Sigma$ & 20 & 21 & 12 & 22 & 13 & 16 & 10 & 15 & 13 & 12 & 24 & 21 & 3 & 9 & \\
\hline
\end{tabular}

rope have been implemented in the funerary landscape for cremation practices in Poland.
A comparison of Polish facilities with solutions from Europe shows significant differences on every funerary landscape level (layer): context, natural space, 
built space and sense of place. The main factor determining the poor implementation of multifaceted solutions („pattern book“) at selected contemporary Polish landscapes for cremation practices is a lack of consistent regulations when it comes to planning funeral facilities. Crematoria and cemeteries are considered as a building, according to Polish Classification of Building Facilities. That is why, the professional group responsible for designing funeral landscapes are architects. Therefore, it is only up to the goodwill of an architect as to whether an interdisciplinary team with landscape architects will be constituted. It is unlike in other European countries, where "originally, the design of funerary places is a classic subject in the field of landscape architecture" (Keddemann 2011, p. 15). Landscape architects are in charge of the overall design and arrangement of crematoria surrounding and cemeteries, which is also emphasized by the EFLA (European Foundation of Landscape Architecture), e.g., Belgium, Denmark, France, Germany.
Context. Most Polish funerary places have no connection with the surrounding landscape. Walls and fences separates cemeteries and crematoria from landscape qualities and daily life.

The increase in public interest in cremation caused that in the historical, already formed tissue of many cemeteries, a place for the crematorium had to be found. For example, at the Miłostowo cemetery in Poznań, Fort III was adapted for the crematorium. At the Central Cemetery in Szczecin and municipal cemetery Rzeszów-Wilkowyja, the crematorium was organized in the cemetery chapel, while in Antoninów and Bytom - in the building of the funeral parlor. In the case of crematoria located in the immediate vicinity of the cemetery, the most commonly used solution is a funeral parlor with a corps incineration service (e.g. Jelenia Góra, Pruszków, Stalowa Wola, Włocławek, Wyszków).

Natural space. Cemeteries and crematoria are treated as buildings in accordance with Polish regula-

Table 7. List of architectural types of crematoria in Poland. Own elaboration

\begin{tabular}{|c|c|}
\hline 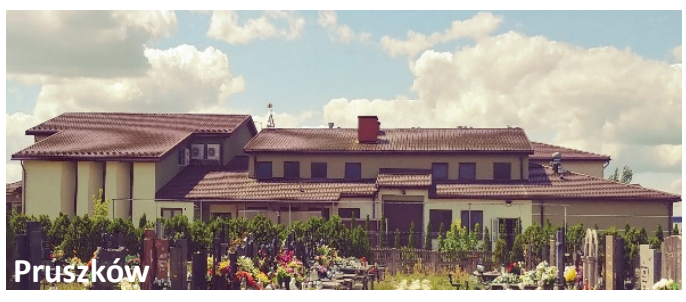 & $\begin{array}{l}\text { FORM OF A CREMATORIUM REFERRING TO RESIDENTIAL ARCHITECTURE } \\
\text { Features: Stylistics of the Polish court; gable, pediment and mansard roofs } \\
\text { Examples: Kalisz; Koszalin Różana St.; Otwock; Wyszków; Pruszków }\end{array}$ \\
\hline Białystok & $\begin{array}{l}\text { FORM REFERRING TO THE SERVICE AND PRODUCTION ARCHITECTURE } \\
\text { Features: No emblems; simple, modern form; concrete, glass (large trans- } \\
\text { parent surfaces), corten } \\
\text { Examples: Gorzów Wielkopolski „Products”; Karakule; Katowice; Lubin; } \\
\text { Nowa Chełmża }\end{array}$ \\
\hline 3 & $\begin{array}{l}\text { FORM REFERRING TO RELIGIOUS ARCHITECTURE } \\
\text { Features: Presence of elements associated with sacred building, i.e. tower, } \\
\text { portico, arcade, belfry, dome, religious emblems (identification of archetypal } \\
\text { sacred elements) } \\
\text { Examples: Antoninów; Bytom; Częstochowa; Gorzów Wielkopolski; Łódź; } \\
\text { Słupsk; Wrocław }\end{array}$ \\
\hline
\end{tabular}


tions. The professional group responsible for designing these facilities are architects. There are only few examples of funeral places, which expand natural features (such as wood lots and meadows) from surrounding sites onto the crematorium and cemetery complex in order to increase total available habitat (Antoninów, Częstochowa).

Built space. The design approach, dominating in Poland in the context of crematoria, represents the current of modernist, universal architecture, showing no signs of locality, in which the element of sacrum is hidden by a far-reaching metaphor. A common feature of the crematoria studied is the colour of the façades resulting from universal preferences for earth colours and nature. The colours used are dominated by brown and rust (using corten steel, brick and clinker, e.g. crematoria in Częstochowa, Jaszków, Poznań, Ruda Śląska, Szczecin). This range of colours is associated with symbolism. These shades indicate transience, the relationship of man with the earth ("you are dust and to dust you shall return"). The solids and the way they are separated, leading out window openings, indicate the closing of objects to the surroundings, cutting off from the context. In few Polish crematoria (e.g. Stalowa Wola, Gorzów Wielkopolski: "Products" and "Gorzowski
Dom Pogrzebowy", Rzeszów) glazed surfaces create the impression of fluidity, penetration of space and indicate the integration of the world of the living and the dead. Although contemporary architecture is accompanied by a typological uniformity process, an analysis of the spatial forms of crematoria in Poland indicates a certain variety. Three directions of shaping the body dominate, referring to residential, service and production and sacred architecture (Table 7).

In the amended Act on Cemeteries and Burial of Deceased, which entered into force in Poland on January 1,2007 , the ashes of the deceased were not allowed to be scattered in cemetery memorial gardens. Thus, Poland found itself among the countries with the most restrictive regulations in the context of handling the body of a deceased (Dziewulak 2012). Before the amendment, the Act on Cemeteries and Burial of Deceased (1959) did not regulate the issue of dispersing the ashes and establishing "the memorial gardens", hence the interpretation that what is not prohibited is permissible - cemetery managers established memorial gardens and meadows. Along with the amendment to the Act, the catalogue of spatial forms dedicated to commemorating a person as a result of incineration has been significantly re-

Table 8. List of columbaria types found in Polish funerary landscape. Own elaboration

\begin{tabular}{|c|c|c|c|}
\hline Columbarium type & Form & Features & Examples \\
\hline $\begin{array}{l}\text { Wall, so-called urn } \\
\text { wall }\end{array}$ & - & $\begin{array}{l}\text { most often located on the main axis } \\
\text { of the cemetery or on its outskirts } \\
\text { thus marking the borders }\end{array}$ & $\begin{array}{l}\text { Jaszków, } \\
\text { Koszalin, } \\
\text { Antoninów, } \\
\text { Szczecin }\end{array}$ \\
\hline $\begin{array}{l}\text { Columnar, so-called } \\
\text { urn steles }\end{array}$ & 5 & $\begin{array}{l}\text { urn niches are located on top of } \\
\text { each other (usually has from } 2 \text { to } \\
4 \text { levels of urn niches); located on } \\
\text { hard surface pavements or on lawns }\end{array}$ & Częstochowa \\
\hline Courtyards & 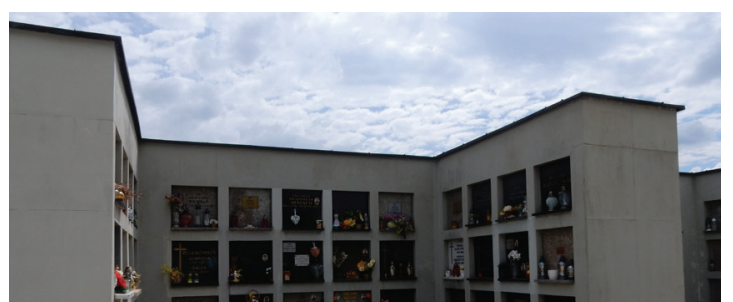 & $\begin{array}{l}\text { configuration of wall columbaria, } \\
\text { which creates a closed, usually } \\
\text { quadrilateral, courtyard; closed } \\
\text { form allows to cut off from the } \\
\text { environment by creating a special } \\
\text { space of contemplation, reflection } \\
\text { and quietness }\end{array}$ & $\begin{array}{l}\text { Antoninów, } \\
\text { Warszawa }\end{array}$ \\
\hline
\end{tabular}



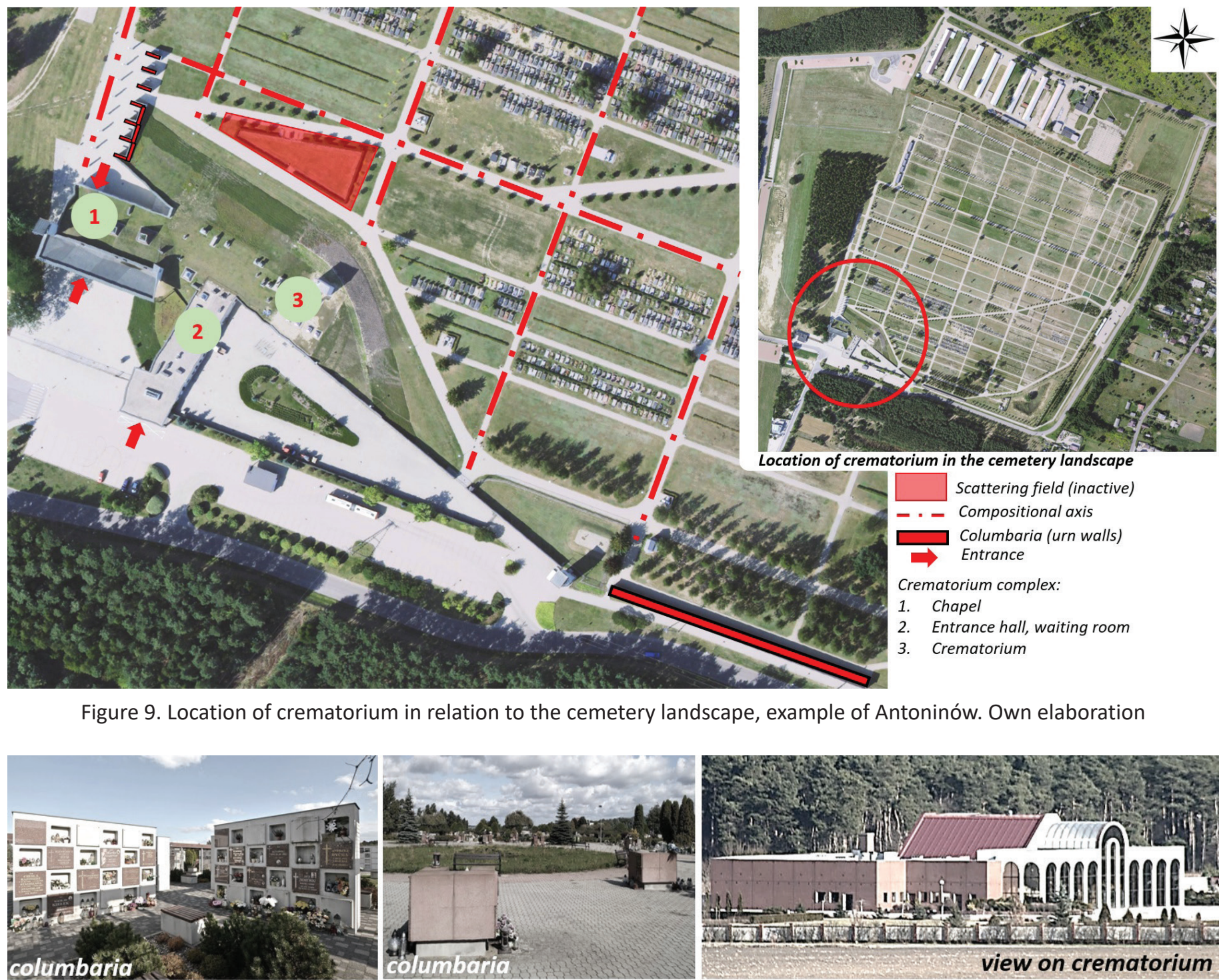

Location of crematorium in the cemetery landscape

Location of crematorium in the cemetery landscape

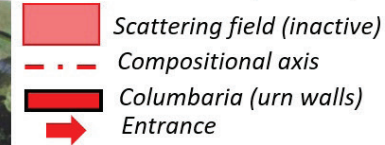

Crematorium complex:

1. Chapel

2. Entrance hall, waiting room

3. Crematorium

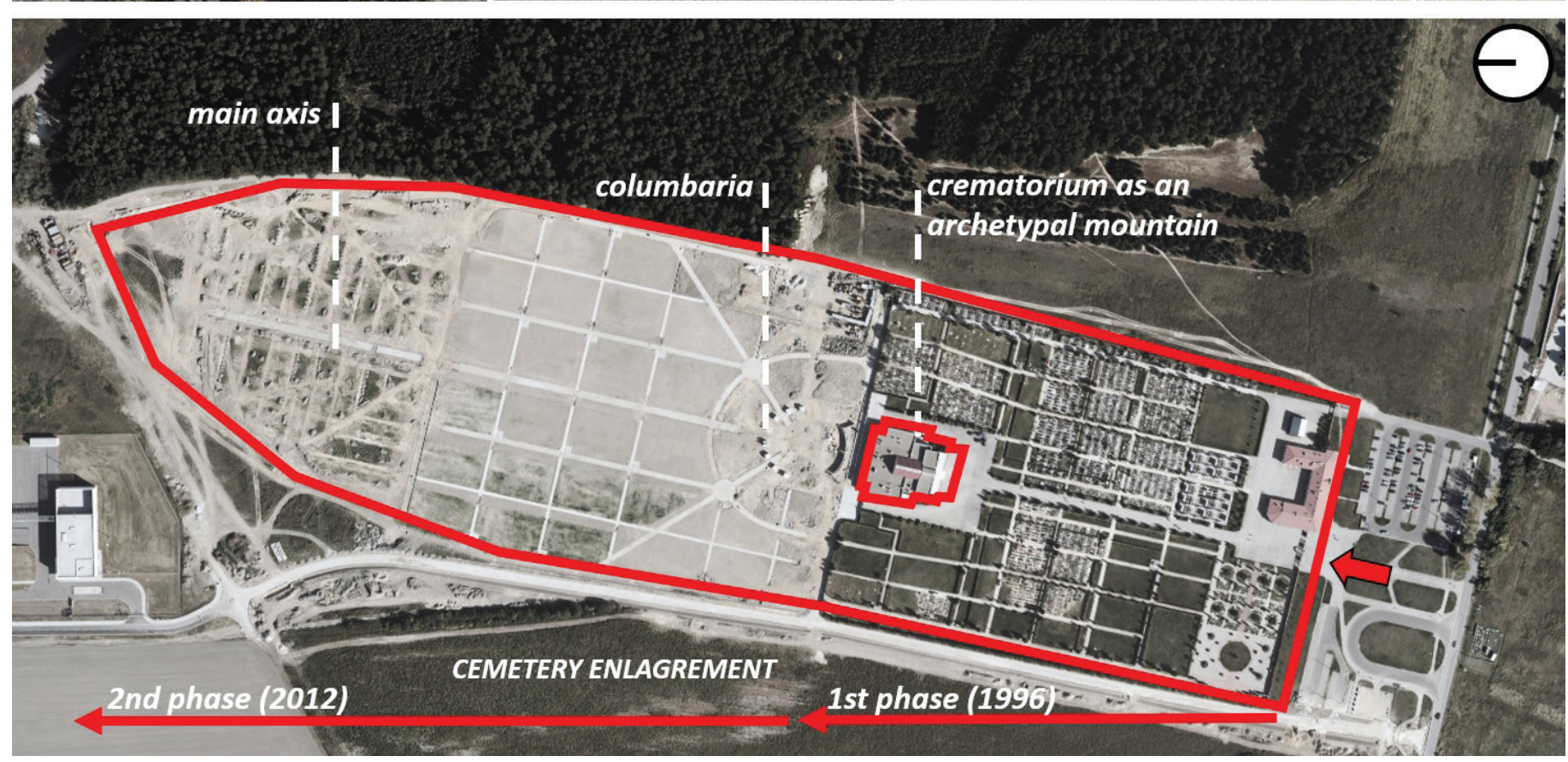

Figure 10. Crematorium in the program and structure of the cemetery affects its composition, municipal cemetery in Wrocław. Own elaboration 
duced. Until 2007, there were memorial gardens in Poland at the following municipal cemeteries with crematorium: Poznań, Antoninów (memorial meadow founded in 1998), Ruda Śląska (memorial garden for anonymous burials founded in the second half of the 1990s), Szczecin (memorial garden at the Central Cemetery launched in 2005). While traditional burial fields are almost devoid of equipment in the field of small architecture - they become an important element of development at columbaria. Often complementary elements for columbarium solutions are seats, water and sculptural elements (Table 8).

In the functional and spatial structure of the Polish cemetery, the crematorium is:

A. located in a multifunctional facility, in which, apart from the incineration plant, there are rooms dedicated to administrative and funeral services (florist, dissecting room, funeral parlor); e.g.: Antoninów - Figure 9, Częstochowa, Nowa Chełmża, Ruda Śląska, Warsaw;

B. an independent architectural object (in the cemetery space, there are many buildings dedicated to funeral functions); e.g. Jaszków, Dąbrowa Górnicza, Wrocław - Psie Pole.

The municipal cemetery in Wrocław was originally (in the first stage of the investment) at the close of the main axis (main avenue). As a result of the necropolis expansion, after 2011, the crematorium became the main element structuring its space. The monumental body of the cremation "stitches" and integrates the spaces created in two stages of expansion: an orthogonal plan with an older provenance and rectangular avenues complemented by communication paths running in an arc with wall and columnar colonies created during the cemetery expansion.

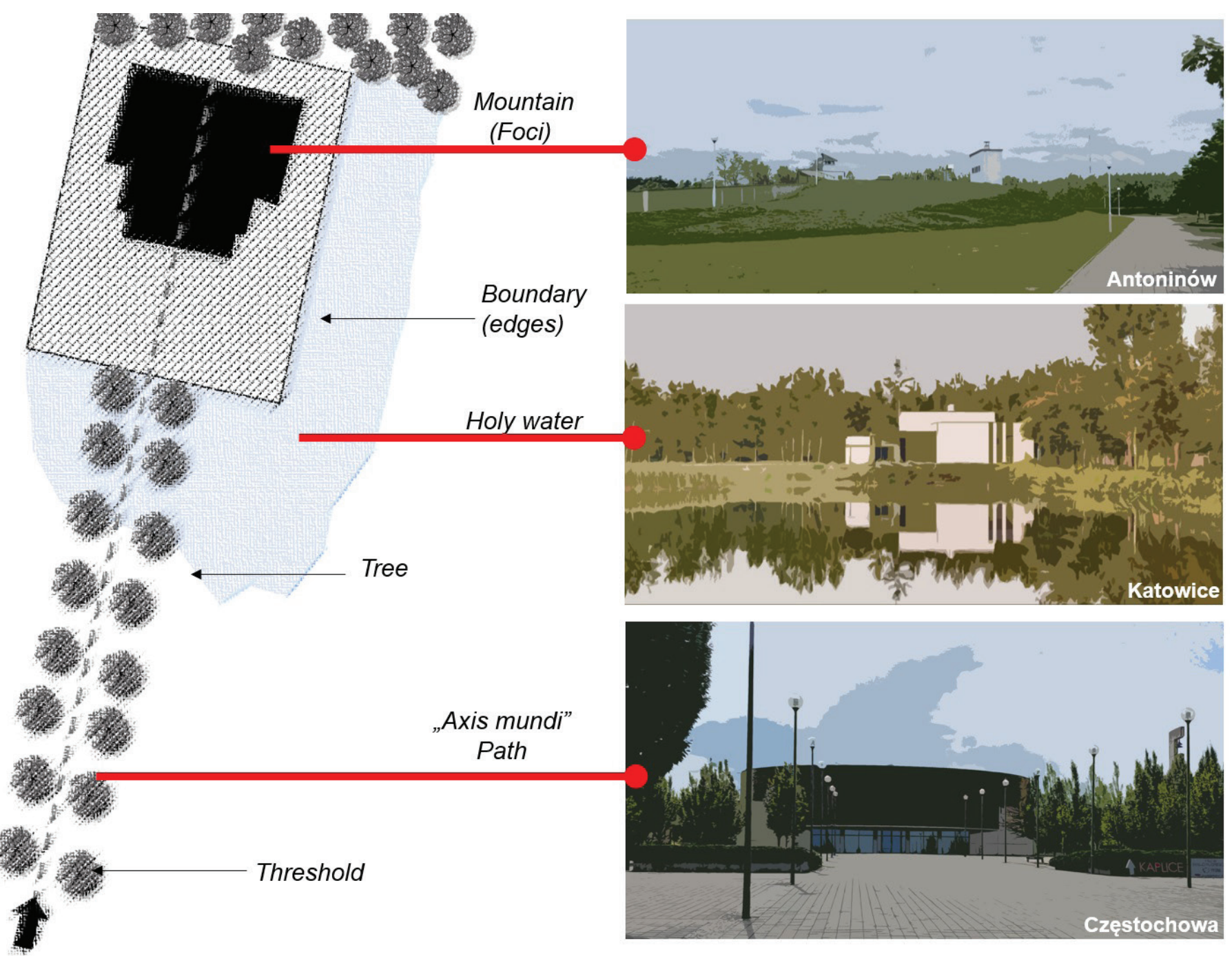

Figure 11. Multifaceted funerary landscape in Poland. Own elaboration 


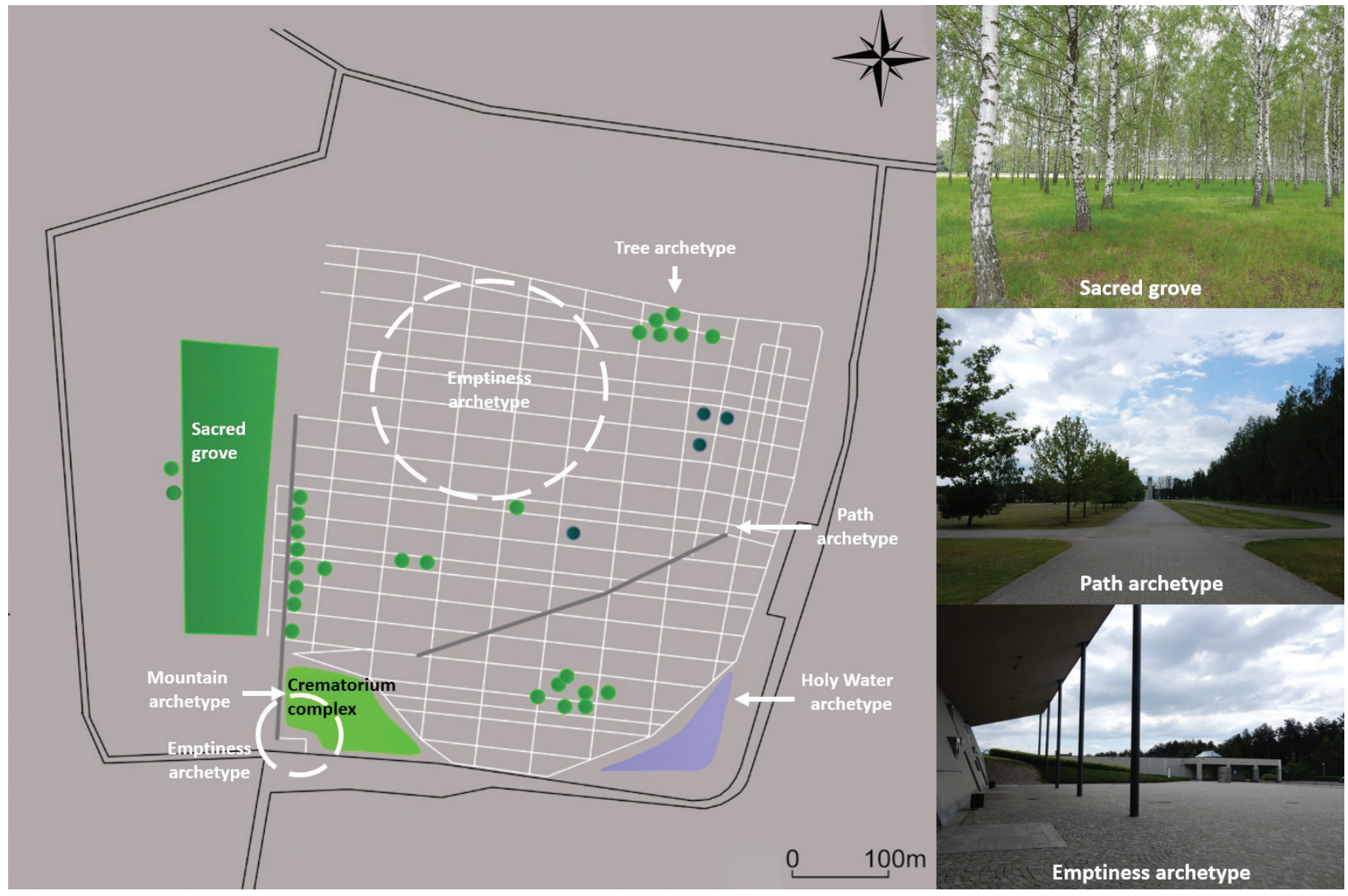

Figure 12. Spatial assumption with crematorium in Antoninów as an example of site that implement design solutions of multifaceted funerary landscape. Own elaboration

The body of the crematorium emphasizes the centre of layout and legible division of space into a representative and burial part (Figure 10).

Sense of place. There are single components - archetypal elements sacralising the funeral landscape in Polish research sites. The most outstanding, remarkable design solutions are presented in the Figure 11 above. In Poland, there are only a few spatial assumptions with crematoria that implement a multifaceted sacred landscape program (Antoninów - Figure 12, Częstochowa, Katowice).

\section{Discussion and conclusions}

Stępa (1993) forecasted that if the number of crematoria in Poland and Denmark were to be shaped in a similar proportion to the population or area of the country, it would mean that in Poland, over 200 such facilities should be built. Thus, 63 crematoria, which were established in 1993-2019, is a prelude to further investment. Undoubtedly, the increase in acceptance for cremation in Poland began the period of forming a new face of landscape, in which the crematorium, columbarium, plays an important role, which is the evidence of a change in the area of death perception and in the quality and manner of shaping the death landscape and burial culture. Limited space and the practice of single grave use will inevitably lead to a lack of room for the continually growing "departed" population. That is why, the utilitarian nature of cremation is strongly articulated in Europe due to demographic forecasts and urbanization. Maddrell et. al (2018) said that diversity-ready cemeteries and crematoria are a necessary but currently neglected aspect of an inclusive and integrated multicultural society. Inappropriate, random location (and structure) of places dedicated to cremation can have negative impact not only on the space, but above all on people. Moreover, Davies and 
Bennett (2016) named objects from the category of deathscape, including cemeteries and crematoria, "planning conundrum". This is due to the multifaceted nature of the space in which objects dedicated to the incineration and commemoration of cremated human ashes are inscribed. They are religious and architectural facilities at the same time. Therefore, making recommendations is necessary.

The most important paradigms in designing funeral places to accommodate increasing cremation practices in Europe should be: accessibility, connectivity and identity.

Context. Locating the contemporary cemetery and crematorium investments in complete isolation in open areas is a common case. This "pushing to the periphery of modern cities", on the canvas of Thomas's research (1980), should be considered a desire to hide, the subconscious fear of death. In the past, cemetery areas accompanied sacred buildings and formed an integral architectural and landscape whole with them (Długozima, 2014; Dexeus, 2015). Perhaps, it was a kind of earthly way of guarding the sacred world of the dead, the modern reminiscence of which is the cemetery-crematorium relationship. This confirms the sacred (crematorium as a religious facility in accordance with the Polish Classification of Building Facilities) (1999) and at the same time the ecumenical nature of the corpse incinerator. Walls and fences separates cemeteries and crematoria from daily life and landscape qualities. Including the landscape could provide identity for the place, relativity in daily life, and provide contemplation and consolation at funerary places.

Context guidelines: The choice of place plays an important role in the process of creating a spatial assumption from the crematorium. Funerary place should be a part of the landscape. It should be more visible in the landscape, because death is part of life. Hiding does not let the death disappear. And remarking a funerary place can be a source of perspective and contemplation.

Natural space. Most Polish crematorium complex have no connection with the surrounding landscape. There is lack of greenery in crematorium site arrangement. There is no integration with land form and natural plants.
Natural space guidelines: Within an emotional situation, nature can give consolation. Landscape architects should be retained for the design of the crematorium surrounding grounds and gardens. It is important to get quick growing trees and shrubs planted at once, with a long-term planting scheme for forest trees for the ultimate screening and maturing of the site. To create funeral places connected with the surrounding landscape local resources are recommended to use. For example, the local conservation authority can provide a list of native species that are suited to the site. Interesting guidelines corresponding to this paper are developed in studies about enhancing the ecological value of funeral places (cemeteries) e.g. Relyea (2013), Clayden et al. (2014, 2018), Długozima and Kosiacka-Beck (2020).

Built structure. Research shows that the architectural form of crematoria is constantly evolving, reflecting trends that can be observed in the development of European architecture. The first incineration facilities referred to the ideas of public utility architecture and the direct reference point for them was sacred architecture. It was only with the spread of modernist forms in the body of the incineration plant that the function of the object began to be exposed. In this regard, the author's observations coincide with the results by Stępa (1993) and Åhrén (2009) studies. The architectural solutions used today are typical for residential and office buildings. There is a lack of strong architectural articulation of the crematorium in Poland. It has been reduced to a utilitarian space. The form of crematoria is supposed to be detached from the ultimate, incline to forget about death and emptiness (only a careful analysis of the applied means of artistic expression allows to learn about the Thanatos purpose of buildings). The "unworked" spatial form of crematorium, columbarium may deepen the socio-cultural problem with perception and acceptance of death.

Built structure guidelines: The crematorium body should be embedded in the local space (form, colour, materials, and textures). Integration of landscape conditions and spatial form is to contribute to the familiarization of society with the subject of death. Design of deathscape should have a sacred and phenomenological aspect. 
Table 9. Funerary landscapes for cremation practices and the ways of integration into the surrounding landscape. Own elaboration

\begin{tabular}{|c|c|c|c|}
\hline \multicolumn{4}{|c|}{ Funerary landscapes for cremation practices - types } \\
\hline Features & $\begin{array}{l}\text { Strong integrated into the sur- } \\
\text { rounding landscape }\end{array}$ & $\begin{array}{l}\text { Medium integrated into the } \\
\text { surrounding landscape }\end{array}$ & $\begin{array}{l}\text { Weak integrated into the sur- } \\
\text { rounding landscape }\end{array}$ \\
\hline $\begin{array}{l}\text { Crematorium ("C") } \\
\text { and cemetery } \\
\text { landscape ("CL") } \\
\text { relations (build- } \\
\text { ing transparency, } \\
\text { colours) }\end{array}$ & $\dot{c}$ & $c_{4}$ & $\mathrm{CL}$ \\
\hline $\begin{array}{l}\text { Crematorium ("C") } \\
\text { in cemetery land- } \\
\text { scape position }\end{array}$ & main entrance & main entrance & \begin{tabular}{|c|}
\multicolumn{1}{c}{} \\
main entrance \\
\end{tabular} \\
\hline $\begin{array}{l}\text { Funeral land- } \\
\text { scape ("FL") and } \\
\text { surrounding ("S") } \\
\text { relations (type of } \\
\text { edges - integra- } \\
\text { tion) }\end{array}$ & 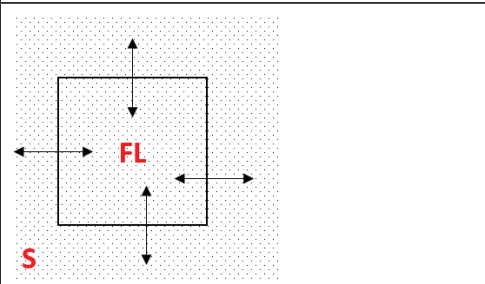 & $\begin{array}{ll} \\
\\
\mathrm{FL}\end{array}$ & s \\
\hline $\begin{array}{l}\text { Visibility of funeral } \\
\text { landscape facilities } \\
\text { (scale of crematori- } \\
\text { um building) }\end{array}$ & 1 & 1 & 1 \\
\hline $\begin{array}{l}\text { Crematorium } \\
(\text { "C } C \text { ") and space } \\
\text { for interment (“I") } \\
\text { relations }\end{array}$ & 1 & $\begin{array}{l}\text { SQUARE AROUND } \\
\text { BUILING } \\
\text { Crematorium forms a bridge } \\
\text { between the entrance and the } \\
\text { interment space }\end{array}$ & 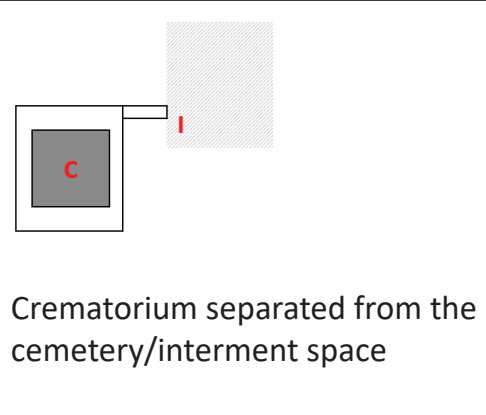 \\
\hline $\begin{array}{l}\text { Space organisation } \\
\text { of funeral land- } \\
\text { scape (division into } \\
\text { intimate space and } \\
\text { public space) }\end{array}$ & $\begin{array}{l}\text { Community (crematorium) and } \\
\text { contemplative, individual spaces } \\
\text { (greenery arrangements) }\end{array}$ & $\begin{array}{l}\text { Clear main structure (main axis, } \\
\text { promenade) and a lot of free- } \\
\text { dom in the sub-structures }\end{array}$ & $\begin{array}{l}\text { Public and private space within } \\
\text { crematorium (courtyards, patios) }\end{array}$ \\
\hline $\begin{array}{l}\text { Layout (design) of } \\
\text { funeral landscape }\end{array}$ & $\begin{array}{l}\text { Using existing landscape features } \\
\text { (relief, water, green), curving } \\
\text { paths, irregular, varied greenery }\end{array}$ & $\begin{array}{l}\text { Geometrical with greenery } \\
\text { arrangements (hedges, rhythmic } \\
\text { of trees) }\end{array}$ & $\begin{array}{l}\text { Geometrical, rectangular style; } \\
\text { uniform, ordered, rhythmic, } \\
\text { monumental, domination of built } \\
\text { space, the open air space adja- } \\
\text { cent to the crematorium }\end{array}$ \\
\hline $\begin{array}{l}\text { Surrounding } \\
\text { (topos) }\end{array}$ & Forest, park-like grounds & Agricultural, open field & $\begin{array}{l}\text { Urban, industrial (green room in } \\
\text { the city/ in the city outskirts) }\end{array}$ \\
\hline
\end{tabular}


Sense of place. The form of the crematorium, without a knowledge of what and how it signifies, may not convey any religious sense whatever.

Sense of place guidelines: Since the crematorium is a sacred object, archetypal design elements (tree, holy water, sacred mountain, paths, thresholds, foci, and boundary) should play an important role in shaping its surroundings. Applying archetypal themes and forms to the site also allows visitors of all denominations to connect their pain and grief with that of the past. These archetypes become a common human bond, a connection and ritual between all people for a final journey that will be taken by every human, regardless of religion, race or creed (Wasserman, 2002; Higgins, 2010).

Finally, a list of types of funerary landscapes has been developed, taking into account the degree of their integration with the surrounding landscape (Table 9).

Because cemeteries and crematoria are multifaceted, architectural and sacral aspects, therefore, interdisciplinary research on cremation should be continued. Due to different meanings and roles assigned to crematoria and cemeteries (in the aspect of deposition of human ashes) by tradition, science, and the extreme perception of this space: from a usable place, through a symbolic, sacred place to a place of specific social activity, research should be continued and developed, and actions that will restore the features of cemeteries characteristic of the sacred zone and will distinguish them in the Polish and European cultural landscape.

\section{Acknowledgements}

This research was funded by National Science Centre grant "Planning cemeteries in the existing urban and rural structures in Poland, seen from the spatial order aspect, against the background of the contemporary European sepulchral space" (No. 2016/23/D/ HS4/03043).

I would like to thank two anonymous Reviewers for valuable and constructive comments and suggestions that greatly improved the manuscript.

\section{References}

Act on Cemeteries and Burial of Deceased (Ustawa o cmentarzach ichowaniu zmarłych), Journal of Laws 1959, No. 11, item 62. http://prawo.sejm.gov.pl/ isap.nsf/DocDetails.xsp?id=WDU19590110062 (Accessed: 20.12.2019).

Åhrén, E. 2009. Death, modernity and the body. Sweden 1870-1940, New York: University Rochester Press.

Ardekani, R.; Akhgar, H. \& Zabihi, H. 2015. Cemetery as a Sociocultural Space in the Persian Cities. International Journal of Architecture and Urban Development 5 (2), 57-68.

Ariès, P. 1974. Western Attitudes Toward Death from the Middle Ages to the Present, Baltimore: John Hopkins University Press.

Barrie, T. 1996. Spiritual Path, sacred place. Myth, ritual, and meaning in architecture, Boston: Shambhala.

Berry, M. 1992. Designing for Eternity-The Cemetery Landscape as a Therapeutic Environment, Melbourne, University of Melbourne.

Bhatia, T. 2014. Enhancing Sensory Environments of Crematoria. https:// surface.syr.edu/cgi/viewcontent. cgi?article $=1232 \&$ context $=$ architecture_tpreps (Accessed: 21.12.2019).

Bil, J. 2014. Evidence based design for contemporary healthcare fascillities. Współczesne projektowanie obiektów służby zdrowia oparte na dowodach naukowych. Przestrzeń i Forma. Space \& Form 22, 69-80. 
Bowlby, J. 1969. Attachment and Loss, t. 1 Basic Books, New York.

Burns, D. 2011. Grief and Healing in Architecture. https://issuu.com/davidburns/docs/david_ burns_final_thesis_book (Accessed: 30.12.2019).

Chakraborty, I.; Banerjee, S. 2020. Challenges for Designing of Hindu Crematorium in Puri, Odisha, India. International Research Journal of Engineering and Technology (IRJET) 07 (08), 13531364.

Chrysikou, E. 2014. Architecture for Psychiatric Environments and Therapeutic Spaces. Amsterdam-Berlin-Tokyo-Washington, IOS Press. DOI: 10.3233/978-1-61499-460-2-i

Clayden, A.; Green, T.; Hockey, J. \& Powell, M. 2014. Natural Burial: Landscape, Practice and Experience. London, Routledge Taylor \& Francis Group.

Clayden, A.; Green, T.; Hockey, J. \& Powell, M. 2018. Cutting the lawn - Natural burial and its contribution to the delivery of ecosystem services in urban cemeteries. Urban Forestry \& Urban Greening 33, 99-106. DOI: 10.1016/j. ufug.2017.08.012

Colombo, A. 2017. Why Europe has never been united (not even in the afterworld): The fall and rise of cremation in cities (1876-1939). Death Studies 41, 22-33. DOI: 10.1080/07481187.2016.1257881

Daróczi, T.T. 2012. Death, Disposal and Social Memory - Towards a Definition of Funerary Landscapes. Journal for Ancient Studies 3, 199-207.

Davies, D.J.; Mates, L.H. (eds.). 2005. Encyclopedia of Cremation, London: Ashgate.
Davies, P.J.; Bennett, G. 2016. Planning, provision and perpetuity of deathscapes. Past and future trends and the impact for city planners. Land Use Policy 55, 98-107. DOI: 10.1016/j. landusepol.2016.03.029

Davies, D., 1996. The Social Facts of Death. In: Howarth G., Jupp P.C. (eds) Contemporary Issues in the Sociology of Death, Death, Dying and Disposal. London, Palgrave Macmillan, 17-29. DOI: 10.1007/978-1-349-24303-7_2

Day, Ch. 1990. Places of the Soul: Architecture and Environmental Design as a Healing Art. London, The Aquarian Press.

Dee, C. 2001. Form and fabric in landscape architecture: A visual introduction, London - New York, Spon Press. Taylor \& Francis Group.

Dexeus, A. 2015. The bones of our ancestors. The end of burials in churches in the late 18th century. Contributions to Science 11, 85-94. DOI: 10.2436/20.7010.01.216

Długozima, A. 2014. Miejsce i rola cmentarzy w budowaniu krajobrazu sakralnego wsi, na przykładzie Bieszczadów i Warmii (Place and role of the cemeteries in sacred rural landscape creation, on the example of the Bieszczady and Warmia). Teka Kom. Arch. Urb. Stud. Krajobr. - OL PAN X/1, 5-19.

Długozima A., 2017. Miejski krajobraz funeralny: jak projektować miejsca dedykowane śmierci, by sprzyjały terapii, regeneracji i integracji? (Urban funeral landscape. How to design sites dedicated to death for the purpose of therapy, regeneration and integration?). In: Januchta-Szostak A., Banach M. (eds) Człowiek-Ekologia-Architektura. Regeneracja Miasta. Poznań, Wydawnictwo Politechniki Poznańskiej, 97-108. 
Długozima, A.; Kosiacka-Beck, E. 2020. How to Enhance the Environmental Values of Contemporary Cemeteries in an Urban Context, Sustainability, 12(6), 2374. DOI: 10.3390/ su12062374

Dziewulak, D. 2012. Pochówek skremowanych prochów ludzkich na cmentarzach lub w innych miejscach w wybranych państwach Unii Europejskiej oraz w Australii, Kanadzie i USA (Burial of cremated human remains in cemeteries and other places in selected EU countries, Australia, Canada and the United States). BAS. Biuro Analiz Sejmowych 13 (80), 1-8.

Eassie, W. 1875. Cremation of the dead. Its history and bearings upon public health. London, Smith and Elder.

Eliade, M. 1957. The sacred and the profane. The nature of religion. San Diego - New York - London, Harcourt Brace \& Company.

Eriksson, P. 2010. Land for the Dead: Access to and Evolvement of Necral Land in Dar es Salaam, Tanzania. https://www.diva-portal.org/smash/ get/diva2:322191/FULLTEXT01.pdf (Accessed: 21.12.2019).

Etlin, R. 1984. The architecture of death: the transformation of the cemetery in eighteenthcentury Paris. Cambridge, MIT Press.

Gajewska, M. 2009. Prochy i diamenty. Kremacja ciała zmarłego człowieka jako zjawisko społeczne i kulturowe (Ashes and diamonds. Cremation of the body as a social and cultural phenomenon). Kraków, Nomos.

Goyvaerts, S.; Vande Keere, N. 2020. Liturgy and Landscape-Re-Activating Christian Funeral Rites through Adaptive Reuse of a Rural Church and Its Surroundings as a Columbarium and Urn Cemetery. Religions 11(8), 1-13. DOI: 10.3390/ rel11080407
Grof, S.; Halifax, J. 1977. The Human Encounter with Death. New York, Dutton.

Hadders, H. 2013. Cremation in Norway: Regulation, changes and challenges. Mortality 18 (20), 195213. DOI: $10.1080 / 13576275.2013 .786033$

Hamilton, K. 2006. Evidence based design and the art of healing. In: Wagenaar C. (ed) The architecture of hospitals. Rotterdam, Nai Publishers, 271-280.

Hermann, H. 2005. On the transcendent in landscapes of contemplation. In: Krinke R. (ed) Contemporary landscapes of contemplation. London, Routledge, 36-72. DOI: 10.4324/9780203462089

Higgins, J.F. 2010. Deathscapes: designing contemporary landscapes to solve modern issues in cemeteries. https://getd.libs.uga.edu/pdfs/ higgins_jessica_f_201308_mla.pdf. (Accessed: 22.12.2019).

Howarth G., 2007. Death \& Dying: A sociological introduction. Cambridge, Polity Press.

Hultquist A. M., 2013. Dead Space. https:// surface.syr.edu/cgi/viewcontent. cgi? article $=1159 \&$ context $=$ architecture_theses (Accessed: 21.12.2019).

Humprey, C.; Vitebsky, P. 1997. Sacred architecture. Boston, Little, Brown \& Co.

Hupková, M. 2010. Spatial differentiation of necrogeographical aspects in Czechia: Causes, consequences and features in landscape. Folia geographica 15, 27-42.

Hupková, M. 2014. The link between the popularity of cremation in the Czech Republic and religious faith. Prace Geograficzne 137, 69-90. 
Idem, R. 2015. Tanatoarchitektura [=] Thanatoarchitecture. In: Idem R., GębczyńskaJanowicz A. (eds) Architektura służby zdrowia. Problematyka projektowa. Gdańsk, Wydawnictwo Politechniki Gdańskiej, 131-144.

Javeau, C. 2001. The re-ritualization of cremation ceremonies in Belgium. Mortality 6 (3), 245-246. DOI: 10.1080/13576270127018

Jupp, P.C. 1980. From Dust to Ashes: the Replacement of Burial by Cremation in England 1840-1967. London, Congregational Memorial Hall Trust.

Jupp, P.C. 2005. From Dust to Ashes. Cremation and the British Way of Death. London, Palgrave Macmillan. DOI: 10.1057/9780230511088

Keddemann, S. 2011. Funerary places: between emotion and design. The essence of cemetery and crematorium design. https://edepot.wur. nl/187401 (Accessed: 15.10.2020).

Kellehear, A. 1984. Are we a 'death-denying' society? A sociological review. Social Science and Medicine 18, 713-723.

Kerrigan, M. 2007. The History of Death: Burial Customs and Funeral Rites, from the Ancient World to Modern Times. Guildford, Connecticut, Lyons Press.

Klaassens, M.; Groote, P. 2012. Designing a place for goodbye: The architecture of crematoria in the Netherlands. In: Davies D., Park C. (eds) Emotion, identity and death: Mortality across disciplines. London, Ashgate Publishing, 145-159.

Klaassens, M.; Groote, P. 2014. Postmodern crematoria in the Netherlands: A search for a final sense of place. Mortality 19 (1), 1-21. DOI: 10.1080/13576275.2013.843511
Kok, H.L.; Wille, A. \& Boerhof, G. 1994. Begraven \& begraafplaatsen, monumenten van ons bestaan. Utrecht, Stichting Teleac.

Kong, L. 1999. Cemetaries and columbaria, memorials and mausoleums: narrative and interpretation in the study of deathscapes in geography. Australian Geographical Studies 37, 1-10. DOI: 10.1111/1467-8470.00061

Krinke, R. 2005.Contemplativelandscapes, restorative landscapes. In: Krinke R. (ed) Contemporary landscapes of contemplation. London, Routledge, 107-138. DOI: 10.4324/9780203462089

Laqueur, T. 2015. The Work of The Dead. A cultural history of mortal remains. Princeton: Princeton University Press.

Leaney, J. 1989. Ashes to Ashes: Cremation and the Celebration of Death in Nineteenth-Century Britain. In: Houlbrooke R. (ed) Death, Ritual and Bereavement. London-New York, Routledge, 118135.

Lewicka, B. 2017. Nekropolie. Socjologiczne stadium cmentarzy Katowic (Necropolis. Sociological Study oft he Cemeteries of Katowice). Katowice, Wydawnictwo Uniwersytetu Śląskiego.

Maddrell, A.; Sidaway, J.D. 2010. Deathscapes: Spaces for death, dying, mourning and remembrance. Farnham, Ashgate Publishing.

Maddrell, A.; Beebeejaun, Y.; McClymont, K.; Mathijssen, B.; McNally, D. \& Abid Dogra, S. 2018. Diversity-Ready Cemeteries and Crematoria in England and Wales: Briefing Note. http://www. deathscapesanddiversity.org.uk

(Accessed: 20.01.2020). 
Mathijssen, B. 2017. The ambiguity of human ashes: Exploring encounters with cremated remains in the Netherlands. Death Studies 41, 34-41. DOI: 10.1080/07481187.2016.1257882

Mathijssen, B; Venhorst, C. 2019. Funerary Practices in the Netherlands. Emerald Publishin Limited. DOI: $10.1108 / 9781787698734$

Fry, E.M. 1969. The Design of Crematoria. Journal of the Royal Society of Arts 117, 256-268.

McCoyd, J.L.M.; Walter, C.A. 2016. Grief and Loss Across the Lifespam. New York, Springer Publishing Company LLC.

Mitrione, S.; Larson, J. 2007. Healing by Design: Healing Gardens and Therapeutic Landscapes. Implications 2(10), 1-6.

Moon, B. (ed) 1991. An Encyclopedia of Archetypal Symbolism. The Archive for Research in Archetypal Symbolism. Boston, Shambhala Publications Inc.

Nešporová, O. 2007. Believer Perspectives on Death and Funeral Practices in a Non-believing Country. Sociologický časopis/Czech Sociological Review 43, 1175-1193.

Nešporová, O. 2020. Funerary Practices in Czech Republic. Emerald Publishing Limited.

Palánová, K.; Kovář, J.; Babor, T.; Dlábiková, I. \& Juračka, O. 2015. Requirements for cremation architecture in contemporary secularized society. Requisiti per l'architettura della cremazione nella contemporanea società laica IN_BO. Ricerche e progetti per il territorio, la città e l'architettura. 6, 150-158.

Parsons, B. 2003. The funeral and the funeral industry in the United Kingdom. In: Bryant, C.D. (ed) Handbook of death and dying. Thousand Oaks, SAGE, 611-618.
Pham, H. 2014. RE-DESIGNING DEATH An Expression of the Human Bereavement Process through Crematoria Design. https://unitec.researchbank. ac.nz/handle/10652/3081

(Accessed: 03.06.2020).

UN-Habitat, 2009. Planning Sustainable Cities Global Report on Human Settlements, Part I. Challenges and context. https://mirror.unhabitat. org (Accessed: 11.09.2019).

Polish Classification of Buildings Facilities (Polska Klasyfikacja Obiektów Budowlanych), 1999. Journal of Laws of 1999, No. 112, item 1316. http://prawo.sejm.gov.pl/isap.nsf/DocDetails. xsp?id=WDU19991121316 (Accessed: 30.12.2019).

Prothero, S. R. 2001. Purified by fire: a history of cremation in America. Berkeley, University of California Press.

Rebay-Salisbury, K. 2013. Inhumation and cremation: how burial practices are linked to beliefs. In: Sørensen M.L.S., Rebay-Salisbury K. (eds) Embodied Knowledge: Historical Perspectives on Belief and Technology. Oxford, Oakville, Oxbow Books, 15-26. DOI: 10.2307/J.CTVH1DX2T.5

Regulation of the Council of Ministers on the definition of types of projects that may significantly affect the environment (Rozporządzenie Rady Ministrów w sprawie określania rodzajów przedsięwzięć mogących znacząco oddziaływać na środowisko), 2004. http://prawo.sejm.gov.pl/ isap.nsf/download.xsp/WDU20042572573/O/ D20042573.pdf (Accessed: 20.12.2019).

Regulation of the Council of Ministers on the definition of types of projects that may significantly affect the environment (Rozporządzenie Rady Ministrów w sprawie określania rodzajów przedsięwzięć mogących znacząco oddziaływać na środowisko), 2010.http://prawo.sejm.gov.pl/ isap.nsf/download.xsp/WDU20102131397/O/ D20101397.pdf (Accessed: 20.12. 2019). 
Ronnberg, A.; Martin, K. (eds) 2010. The book of symbols: Reflections on archetypal images. Cologne, Taschen.

Rugg, J. 2006. Lawn cemeteries: the emergence of a new landscape of death. Urban History 33(2), 213 - 233. DOI: 10.1017/S0963926806003786

Rugg, J.; Parsons, B. 2018. Funerary Practices in England and Wales. Emerald Publishing Limited. DOI: 10.1108/978-1-78769-223-720181010

Sanders, C. 1999. Grief: The Mourning After. Dealing with Adult Bereavement. New York, John Wiley \& Sons.

Supreme Audit Office/Najwyższa Izba Kontroli, 2016. Zarządzanie cmentarzami komunalnymi (Municipal cemeteries management). https:// www.nik.gov.pl/plik/id,12230,vp,14613.pdf (Accessed: 21.12.2019).

Stępa, T. 1993. Przestrzenne aspekty kremacji (Spatial aspects of cremation). http://pbc.gda.pl/dlibra/ doccontent?id=12801 (Accessed: 21.10.2019).

Suchecki, Z. 2009. Kremacja w kulturach świata (Cremation in world cultures). Kraków, Wydawnictwo Salwator.

Svobodová, M. 2013. The Crematorium in the Process of Secularisation in the Czech Lands in the Twentieth Century (Krematorium v procesu sekularizace českých zemí 20. století) Praha, The Czech Academy of Sciences.

Swanson, J. 2017. New Funerary Architecture. Creating Culturally Adaptive Ritual Spaces. https://issuu.com/swanjohnson/docs/swanson_ for_blurb (Accessed: 30.11.2019).
Szukalski, J. 2016. Liczba zgonów w Polsce w przyszłości (Number of deaths in Poland in the future). Demografia i Gerontologia Społeczna Biuletyn Informacyjny 3, 1-4.

Teather, E.K. 1998. Themes from complex landscapes: Chinese cemeteries and columbaria in urban Hong Kong Australian Geographical Studies 36, 21-36. DOI: 10.1111/1467-8470.00037

Teather, E.K. 1999. High-rise homes for the ancestors: Cremation in Hong Kong Geographical Review 89, 409-430. DOI: $10.2307 / 216158$

Thomas, L.V. 1980. Le cadavre. De la biologie a l'anthropologie. Bruxelles, Editions Complexe.

UNESCO, 1972. World Heritage Convention. Convention concerning the protection of the world cultural and natural heritage adopted by the General Conference at its seventeenth session Paris, 16th November 1972, United Nations Educational, Scientific and Cultural Organisation, Paris.

Valentijn, V.; Verhoeven, K. 2018. Goodbye Architecture. The Architecture of Crematoria in Europe. https://issuu.com/nai010publishers/ docs/sneak_preview_goodbye_architecture (Accessed: 30.11.2019).

Van Steen, P.J.M.; Pellenbarg, P.H. 2006. Death and space in the Netherlands Journal of Economic and Social Geography 97, 623-635. DOI: 10.1111/j.1467-9663.2006.00369.x

Vovelle, M. 1983. La mort et l'Occident de 1300 à nos jours. Paris, Gallimard.

Walter, T. 1991. Modern death: Taboo or not taboo? Sociology 25, 293-310. DOI: $10.1177 / 0038038591025002009$ 
Walter, T. 2012. Why different countries manage death differently: a comparative analysis of modern urban societies. The British Journal of Sociology 63, 123-145. DOI: 10.1111/j.14684446.2011.01396.x

Ward, D. 2010. The Healing Landscape. Planning the 'Nature' in Your Cemetery. Catholic Cemetery Magazine 3, 24-25.

Wasserman, J. 2002. Memory embedded. Landscape Journal 21/1, 190-200.

Welch, J.W.; Parry, D.W. (eds) 2011. The tree of life: From Eden to Eternity. Salt Lake City: Deseret Book.

Williams, H. 2011. Cremation and present pasts: A contemporary archaeology of Swedish memory groves. Mortality 16 (2), 113-130.

Worpole, K. 2003. Last Landscapes. The Architecture of the Cemetery in the West. London, Reaktion Books.

Wylie, J. 2007. Landscape. New York, Routledge. 